\title{
Effect of Water on the Electrodeposition of Copper from a Deep Eutectic
}

\section{Solvent}

\author{
P.E. Valverde, T.A. Green and S. Roy \\ Department of Chemical and Process Engineering, University of Strathclyde, Glasgow, \\ Scotland G1 1XJ, United Kingdom.
}

\section{Corresponding Author:}

Todd Green

Department of Chemical and Processing Engineering, University of Strathclyde, Glasgow,

G1 1XJ, United Kingdom

E-mail: todd.green@strath.ac.uk

\section{ORCID}

P.E. Valverde: https://orcid.org/0000-0002-7211-1127

T.A. Green: https://orcid.org/0000-0002-3538-5217

S. Roy: https://orcid.org/0000-0002-3399-035X 


\begin{abstract}
This study has examined the effect of water on the electrodeposition of copper from a deep eutectic solvent (DES). Initial physiochemical measurements showed that the viscosity and resistivity of the DES decreased with added water in the range $1-15 \mathrm{wt} \%$. This reduction in viscosity resulted in an increase in the mass transfer limiting current, without narrowing the electrochemical window or altering the speciation of the copper chloro-complexes. This shows that metal deposition rates can be increased by water additions. The effect of water on the electrochemical kinetics of the $\mathrm{Cu}(\mathrm{I})$ and $\mathrm{Cu}(\mathrm{II})$ chloro-complexes was also studied. It was found that the kinetics of the $\mathrm{Cu}(\mathrm{I}) / \mathrm{Cu}(0)$ reaction is largely irreversible, while the $\mathrm{Cu}(\mathrm{II}) / \mathrm{Cu}(\mathrm{I})$ couple was quasi-reversible. The rate constants for $\mathrm{Cu}(\mathrm{II}) / \mathrm{Cu}(\mathrm{I})$ and $\mathrm{Cu}(\mathrm{I}) / \mathrm{Cu}(0)$ reactions were accelerated by water additions, although the transfer coefficients remained unchanged. The effect of increased deposition rates, electrolyte conductivity and reaction kinetics on deposit uniformity was estimated and subsequently verified by experiments. It was found that, although higher deposition rates could be achieved, the thickness of the deposit was non-uniform since the Wagner numbers remained relatively low.
\end{abstract}




\section{Introduction}

While aqueous systems continue to dominate the electrodeposition of metals, alloys and semiconductors, in recent years there has been considerable interest [1-3] in alternatives such as room-temperature ionic liquids (RTILs). These RTIL systems have a wide electrochemical window and are often used to deposit materials that are either difficult or impossible to deposit from aqueous systems. However, their use in many applications is restricted due to complexities in their synthesis, purification, and high cost. As an alternative to RTILs, deep eutectic solvents (DES) have been proposed [3-6] and have been successfully used to electrodeposit a wide range of metals and alloys. Although their electrochemical window is generally smaller than those of RTILs, they are still larger than aqueous systems and can therefore be used to deposit electronegative metals such as $\mathrm{Cr}$, Ni and $\mathrm{Zn}$ with good current efficiency [7]. Compared to RTILs, DES materials are easy to synthesise, using relatively lowcost precursors and are more tolerant to impurities such as water. They also exhibit low volatility and toxicity, which makes them attractive as sustainable solvents [4-6].

Deep eutectic solvents are typically formulated from a hydrogen bond donor (HBD) and a hydrogen bond acceptor (HBA) [5,7]. When mixed together they self-associate to form a new eutectic phase with a melting point lower than the original components. A prototypical example of an HBA is choline chloride, while the HBD compound is often a diol such as ethylene glycol or a primary amine such as urea. These eutectics are capable of dissolving high concentrations of metal oxide and chloride salts, thus allowing the preparation of electrodeposition solutions. A typical type-III eutectic system ('ethaline') consists of a 1:2 molar ratio of choline chloride to ethylene glycol to which a hydrated metal chloride salt is added [5,7]. These DES are hygroscopic and water miscible, and will adsorb water unless special precautions are taken 
$[8,9]$. Crucially, however, a high water content in some DES systems does not seem to have an adverse on their electrochemical characteristics or chemical stability $[1,3,5]$. This is in contrast to most RTILs where even a relatively small water content can lead to a significant reduction in the electrochemical window or decomposition of the liquid. The tolerance of DES to water contamination, arguably, makes them more attractive for industrial plating processes [3].

Indeed, earlier studies have shown that inclusion of water as a co-solvent can avoid the formation of toxic products at the anode as well as improving overall electrochemical characteristics [8-10]. For example, DES solutions are highly viscous and the diffusivity of the electroactive species are therefore correspondingly low [3-6]. This suppresses deposition rates, which are typically an order of magnitude lower than for aqueous systems. While this can be partially alleviated by using higher temperatures [11] and specialised agitation $[11,12]$, these approaches require additional equipment and energy. The electrical conductivity of RTIL and DES systems are also low compared to conventional molten salts and aqueous systems resulting in high power consumption $[2,3]$ and poor throwing power. Such outstanding issues need to be addressed if RTIL and DES systems are to find wider industrial use [13], and plausibly they could be mitigated by using water as a co-solvent.

Despite the possibility of improved physiochemical and electrochemical properties using DES/water mixtures $[14,15]$, there have been relatively few attempts to examine the effect of water content on plating processes. Earlier studies on nickel $[8,16,17]$ and chromium [18] have shown that the presence of water in DES and RTILs can affect the electrochemical window [8,9] speciation [18,19], and deposit morphology [8]. In other publications [20,21] it has also been shown that the rate of comproportionation (corrosion) reactions involving $\mathrm{Cu}(\mathrm{II})$ species in a DES is strongly influenced by water content. Collectively, these findings suggest that the 
effect of water on DES systems is complex and multi-faceted, and a comprehensive study of water in DESs is required to elucidate its effect on the electrodeposited material.

The aim of the present study is to investigate the effect of water content on the physiochemical and electrochemical characteristics of the electrolyte and its resultant effect on deposit characteristics. Prior studies of copper deposition from ethaline [11,22-24] glyceline [12] and reline $[22,25]$ DES have been carried out with a low $(<1 \mathrm{wt} \%)$ or uncontrolled water content. In particular, we will study the effect of increasing water content on the viscosity and conductivity of the DES electrolyte. A reduction in viscosity offers a route to enhancing mass transfer, and thereby increasing plating rates. However, in doing so, it needs to be demonstrated that the speciation and electrochemical window are not adversely affected.

The effect of these changes on reaction kinetics, especially of the $\mathrm{Cu}(\mathrm{I}) / \mathrm{Cu}(0)$ couple will also be examined. This kinetic information along with the conductivity data can be used to determine the Wagner number - a parameter that can be used to estimate the throwing power of the electrolyte and therefore the deposit uniformity. Finally, these predictions will be verified against experimental measurements of deposit uniformity at different water contents. The findings of this study will allow a comparison of the strengths and weaknesses of metal deposition from DESs against aqueous systems and other solvents.

\section{Experimental}

\subsection{Physiochemical Measurements}

The deep eutectic solvent ('ethaline') was prepared by mixing choline chloride (Sigma Aldrich, $>98 \%$ ) and ethylene glycol (Sigma Aldrich, purity $>98 \%$ ) in a 1:2 molar ratio without further purification or drying. The mixture was then heated and stirred on a hotplate at $60^{\circ} \mathrm{C}$ until a transparent, homogenous melt was formed. The free chloride concentration of the ethaline was 
approximately $4.5 \mathrm{M}$. Thereafter, technical grade hydrated cupric chloride salt $\left(\mathrm{CuCl}_{2} \cdot 2 \mathrm{H}_{2} \mathrm{O}\right.$, Merck, > 99\%) was dissolved in ethaline to prepare a $0.20 \mathrm{M} \mathrm{Cu}(\mathrm{II})$ solution. The water content of the DES was measured with a Hybrid Karl-Fischer Titrator (MKH-700, Kem Kyoto Electronics) using a volumetric method. The ethaline melts prepared typically had initial water content between $0.3-1.0 \mathrm{wt} \%$, but after adding $0.2 \mathrm{M} \mathrm{CuCl}_{2} .2 \mathrm{H}_{2} \mathrm{O}$ this increased by $0.6 \mathrm{wt} \%$ due to the hydration of the salt. Thereafter, DI water was added to prepare DES with water contents of $1-15 \mathrm{wt} \%$.

To determine if the added water affected copper speciation, spectra of the copper-containing ethaline solutions were recorded using a Varian Cary 5000 UV-VIS-NIR spectrophotometer over the wavelength range $200-800 \mathrm{~nm}$ as a function of water content. For these trials, a set of samples was prepared by adding known amounts of DI water to pure ethaline to formulate 1 to $35 \mathrm{wt} \% \mathrm{H}_{2} \mathrm{O}$, and then adding the cupric salt. Due to the high absorption of the solutions, the copper concentration had to be lowered from $0.20 \mathrm{M}$ to $0.05 \mathrm{M}$ and a short $(125 \mu \mathrm{m})$ path length cuvette (Starna DMV Biocell) was employed. All reported spectra are corrected against ethaline blanks.

The density of the DES samples were determined using a $50 \mathrm{ml}$ specific gravity bottle (Fisher Scientific). The conductivity was measured using an InLab730 conductivity probe (Mettler Toledo) at room temperature. The probe was calibrated against a conductivity standard (12.85 $\mathrm{mS} \mathrm{cm}{ }^{-1}$ at $\left.25^{\circ} \mathrm{C}\right)$. The viscosity of ethaline that contained different amounts of water $(1-15$ wt \%) was measured at $25{ }^{\circ} \mathrm{C}$ using a calibrated Rheometer (DHR-2, TA Instruments). The geometry was a flat stainless-steel plate of $40 \mathrm{~mm}$ diameter (TA instruments). Each sample was measured three times to determine the reproducibility. 


\subsection{Electrochemical Measurements}

The initial experiments to determine the electrochemical window of the DES were performed in a jacketed one-compartment electrochemical cell. All subsequent experiments were performed in a jacketed two-compartment electrochemical cell where the counter and working electrode chambers were separated by a low-porosity glass frit. A thermostatic bath was used to pump water through the jacket of the cells so the temperature could be maintained at $25^{\circ} \mathrm{C}$. The cell compartment was sealed from the atmosphere by a glass cover, but no special precautions were taken to exclude water uptake.

Polarisation experiments were performed using a potentiostat (PGSTAT30, Metrohm Autolab) in a conventional three-electrode configuration. A $0.20 \mathrm{~cm}$ diameter platinum disk (area $=$ $0.031 \mathrm{~cm}^{2}$ ) embedded in PTFE insulator was used as the working electrode (WE). Before use, the Pt electrode was polished with 4000 grade SiC paper, rinsed with DI water and dried with $\mathrm{N}_{2}$. The electrode holder was fitted to an EDI101 rotator, which was interfaced to a CTV101 speed controller (Radiometer Analytical). The counter electrode (CE) was a Pt wire (area = $0.75 \mathrm{~cm}^{2}$ ) and the quasi-reference electrode (RE) consisted of Ag wire inserted in an ethaline containing glass tube sealed with a porous glass frit. The RE assembly was placed in a Luggin probe whose tip was positioned within $0.3 \mathrm{~cm}$ of the Pt disk.

Polarisation experiments were performed potentiostatically at a scan rate of $5 \mathrm{mV} \mathrm{s}^{-1}$ and with the electrode rotating between 700 and $2800 \mathrm{rpm}$. For the kinetic (Koutechy-Levich) studies, it was necessary to apply ohmic (IR) compensation. The uncompensated resistance, $R_{\mathrm{u}}$, was measured using a combined impedance analyser and potentiostat (PalmSens4). The ohmic drop was electronically compensated by positive feedback but, due to issues with potentiostat instability, the maximum amount of IR compensation was $80 \%$. 


\subsection{Electrodeposition Experiments and Thickness Measurements}

For the electrodeposition experiments, low-alloy steel disk samples were employed as the working electrode. These were polished using 1200 and 2400 grade SiC paper, rinsed in DI water and then dried with $\mathrm{N}_{2}$. They were then inserted into a polyether ether ketone (PEEK) sample holder (Origalys) and mounted on the shaft of the EDI101 rotator. The area exposed to the solution was $1.2 \mathrm{~cm}^{2}$. This holder is designed such that the disk face is recessed slightly $(0.1 \mathrm{~cm})$ relative to the surrounding insulating surface. The current distribution therefore differs slightly from a conventional, planar rotating disc electrode (RDE) where the disc and insulator are flush. The use of such a system enabled the sample to be removed for analysis of the deposit uniformity. Deposition experiments were performed galvanostatically at a current density corresponding to $80 \%$ of the limiting current at $700 \mathrm{rpm}$.

For the analysis of the deposit uniformity, a nominally $20 \mu \mathrm{m}$ thick copper layer was deposited. A thick nickel layer $(\sim 20 \mu \mathrm{m})$ was then plated over the copper to aid edge retention. The samples were then cross-sectioned, embedded in conductive Bakelite and ground using 1200, 2400 and 4000 grade $\mathrm{SiC}$ paper. This was followed by polishing with a $1 \mu \mathrm{m}$ diamond paste. Deposit thickness was measured using a Brunel SP400 metallurgical microscope at a magnification of $\times 500$. Images of the deposit cross-sections were performed using a Hitachi S3800 SEM. Micrographs were obtained at a magnification of $\times 1000$, and the back scattered detector was used to improve contrast between the layers.

\section{Results and Discussion}

\subsection{Monitoring of $\mathrm{Cu}$ Speciation as a Function of Water Content}


The influence of water on $\mathrm{Cu}(\mathrm{II})$ speciation in the concentration range of $1-40 \mathrm{wt} \% \mathrm{H}_{2} \mathrm{O}$ using UV-Visible spectroscopy is shown in Fig. 1. The UV-Vis spectrum of the cupric salt in ethaline containing $1 \mathrm{wt} \%$ water exhibits three distinct charge-transfer bands whose maxima are located at 239, 290 and $406 \mathrm{~nm}$. These bands are usually assigned [11,19-22] to the tetrachloro-cuprate complex, $\left[\mathrm{CuCl}_{4}\right]^{2-}$. EXAFS studies $[19,26]$ have largely confirmed that this is the dominant $\mathrm{Cu}$ (II) species in ethaline at low water content. However, upon addition of water, the absorbance of the $406 \mathrm{~nm}$ and $290 \mathrm{~nm}$ bands both decrease and are blue shifted. At higher water content (> $35 \mathrm{wt} \%$ ), the 239 and $290 \mathrm{~nm}$ peaks merge to form a broad band around 270 nm. These UV-Vis results in Fig. 1 suggest that at levels up to $40 \mathrm{wt} \% \mathrm{H}_{2} \mathrm{O}$ there are no significant changes in $\mathrm{Cu}(\mathrm{II})$ speciation.

Our results are very similar to those reported by De Vreese [19] who examined that effect of water addition on $\mathrm{Cu}(\mathrm{II})$ speciation in ethaline using UV-Vis and EXAFS. These researchers found that, up to a water content of $50 \mathrm{wt} \%$, the dominant species is $\left[\mathrm{CuCl}_{4}\right]^{2-}$. However, at higher water content chloride ions are displaced by water resulting in the formation of mixed chloro-aqua complexes of the type $\left[\mathrm{CuCl}_{n}\left(\mathrm{H}_{2} \mathrm{O}\right)_{m}\right]^{(2-n)-}$ with $n=1-3$. At very high water content (95 wt\%) the UV-Vis and EXAFS data is consistent with the cupric ion being completely coordinated by water molecules. In a related study [27] of the $\mathrm{Cu}(\mathrm{II})$ speciation in 1-methyl-3-(3-trimethoxysilylpropyl) imidazolium chloride using EXAFS and UV-Vis spectroscopy, it was found that the dominant species was $\left[\mathrm{CuCl}_{4}\right]^{2-}$ up to $40 \mathrm{wt} \%$ water content, and only above $60 \mathrm{wt} \%$ were mixed $\left[\mathrm{CuCl}_{n}\left(\mathrm{H}_{2} \mathrm{O}\right)_{m}\right]^{(2-n)-}$ complexes formed.

Interestingly our results on speciation are in contrast against those observed for other metals in DES systems. For example, from UV-Vis studies it was found [28] that the Ni(II) speciation in ethaline changes from the $\left[\mathrm{NiCl}_{4}\right]^{2-}$ complex to $\left[\mathrm{Ni}(\mathrm{EG})_{3}\right]^{2+}(\mathrm{EG}=$ ethylene glycol $)$ when the 
temperature was raised from $25{ }^{0} \mathrm{C}$ to above $70{ }^{0} \mathrm{C}$, which had a profound effect on electrodeposition. Similarly, XAS and Raman analysis [29] have shown that the Fe(II)

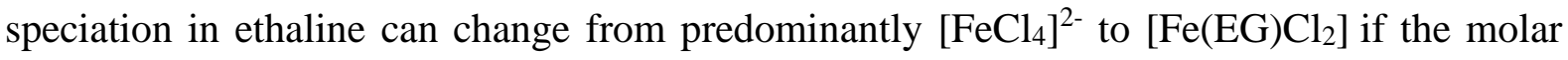
ratio of chloride to iron is reduced below 4:1. Finally, in the chromium ethaline systems it was noted [26] that the addition of $5 \mathrm{wt} \%$ water altered the speciation from $\left[\mathrm{Cr}\left(\mathrm{H}_{2} \mathrm{O}\right)_{2} \mathrm{Cl}_{4}\right]^{2-}$ to $\left[\mathrm{Cr}\left(\mathrm{H}_{2} \mathrm{O}\right)_{4} \mathrm{Cl}_{2}\right]$. However, in the copper ethaline systems the results in Fig. 1 suggest that relatively high water contents (> $40 \mathrm{wt} \%$ ) can be tolerated without significantly altering $\mathrm{Cu}(\mathrm{II})$ speciation. At lower levels of hydration, the $\left[\mathrm{CuCl}_{4}\right]^{2-}$ complex appears stable making it difficult to displace chloride ions with other ligands.

\subsection{Viscosity as a Function of Water Content}

Pure ethaline exhibits a much lower viscosity $\left(36 \mathrm{mPa} \mathrm{s}\right.$ at $\left.25{ }^{0} \mathrm{C}\right)$ compared to other DESs such as glyceline (376 $\mathrm{mPa}$ s) and reline (532 $\mathrm{mPa}$ s) [5,14]. This has been attributed to the fact that ethylene glycol is a weaker hydrogen bond donor than glycerol or urea [14]. A lower viscosity DES is desirable in electrodeposition systems as it strongly influences both the conductivity and mass transport characteristics. The viscosity of DES decreases can be increased by increasing temperature $[3,16]$ but an alternative way is to introduce a co-solvent such as water $[16,30,31]$. The latter approach has advantages in terms of reduced energy consumption, although either method is potentially viable in practical plating situations.

Fig. 2 shows that influence of water addition on the viscosity of pure ethaline and ethaline containing $0.20 \mathrm{M} \mathrm{CuCl}_{2} .2 \mathrm{H}_{2} \mathrm{O}$ at $25{ }^{\circ} \mathrm{C}$. In the former case, the viscosity decreases from 32.1 to $11.7 \mathrm{mPa} \mathrm{s}$ when the water content is increased from $1-15 \mathrm{wt} \%$. Over the same range of water concentrations, the viscosity of the copper containing ethaline was reduced from 47.3 to $15 \mathrm{mPa}$ s. Note that at all water contents the presence of the cupric metal salt results in a higher 
viscosity than for pure ethaline. Comparable trends in viscosity have been reported in earlier studies $[8,14,16,30,31]$ when water is added to pure reline and ethaline and type-III eutectics formulated from hydrated metal chloride salts.

Although most studies report that added water causes a reduction in viscosity, due to the complexity of the DES system, the underlying reasons have not been fully elucidated. One proposal [16,31] makes use of 'hole' theory [32] and explains the reduced viscosity in terms of the increased hole size with added water, which facilitates ionic mobility and viscous flow. An alternative explanation relates to the weakening of the hydrogen bond between the various DES components as water is added. Molecular dynamic simulations [33] indicate that water addition can disrupt the hydrogen bond network, which has been confirmed by neutron diffraction studies [34].

\subsection{Conductivity as a Function of Water Content}

As already noted, DES formulations have a relatively low conductivity $\left(\kappa<1 \mathrm{~S} \mathrm{~m}^{-1}\right)$ compared to typical aqueous systems $\left(\kappa \approx 10-50 \mathrm{~S} \mathrm{~m}^{-1}\right)[2,3]$. As with viscosity, improvements can be attained by operating at higher temperatures [16,31], but using water as a co-solvent is a more cost effective alternative [16,30,31]. For example, Fig. 3 shows that the electrolyte conductivity exhibits a significant improvement from 0.80 to $1.53 \mathrm{~S} \mathrm{~m}^{-1}$ as the water content increased from 1 to $15 \mathrm{wt} \%$. Similar improvement in conductivity with increasing hydration has been reported for many other DES systems [16,30].

As noted by Abbott [2], the conductivity of DES and RTILs is usually governed by the viscosity rather than the total number of ionic species. For DES and RTILs it is possible to derive the following relationship between the conductivity and viscosity $[1,3]$ : 


$$
\kappa=\frac{z^{2} F e \rho}{6 \pi \eta M}\left(R_{+}^{-1}+R_{-}^{-1}\right)
$$

where $z$ is the ionic charge, $F$ is the Faraday constant, $e$ is the electronic charge (C), $\rho$ is the density $\left(\mathrm{g} \mathrm{cm}^{-3}\right), \eta$ is the viscosity $(\mathrm{Pa} \mathrm{s}), M$ is the molar mass and $R_{+}^{-1}$ and $R_{-}^{-1}$ are the radii of the cation and the anion. This equation shows that the conductivity $(\kappa)$ is an inverse function of viscosity $\left(\eta^{-1}\right)$. Fig. 3 indicates that an inverse relationship exists between these two parameters confirming the hypothesis that viscosity largely controls the conductivity. Similar relationships have been reported $[8,16,31]$ for many other eutectic systems containing metal salts.

\subsection{Effect of Water on Electrochemical Window}

Fig. 4 shows the linear scan voltammogram of pure ethaline at a rotating Pt electrode as a function of water content. The electrochemical window is defined as the difference between the anodic and cathodic potential limits corresponding to the electrochemical breakdown of the

DES. These limits were defined as the potential at which the anodic or cathodic current density

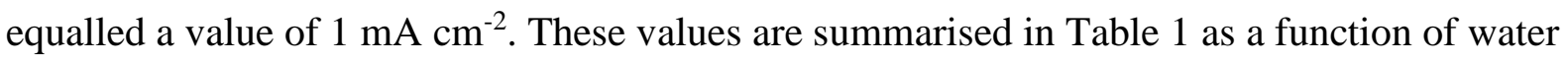
content.

The electrochemical window of ethaline at low water $\left(1 \mathrm{wt} \% \mathrm{H}_{2} \mathrm{O}\right)$ was measured to be $2.1 \mathrm{~V}$, which is in good agreement with the value of $2.0-2.1 \mathrm{~V}$ reported in earlier investigations $[23,35]$. Interestingly, the anodic potential limit is essentially unchanged by water addition, while the cathodic limit is only slightly depolarised. In the latter case, this may be due to the co-reduction of $\mathrm{H}_{2} \mathrm{O}$ as $\mathrm{Pt}$ is generally a good catalyst for hydrogen evolution. However, the overall reduction in the electrochemical window with increasing water is negligible, and even at $15 \mathrm{wt} \% \mathrm{H}_{2} \mathrm{O}$ it is still $2.0 \mathrm{~V}$. This indicate the good overall water tolerance of the ethaline 
system. These findings are in agreement with Al-Murshedi [35] who also observed no significant reduction in the electrochemical window at a platinum electrode in ethaline with water additions up to $50 \mathrm{wt} \%$.

In contrast to the results for ethaline, the effect of water on other DES systems, such as reline, can be significant $[8,36]$. For example, $\mathrm{Du}$ [8] reported that the electrochemical window reduced from $2.54 \mathrm{~V}$ to $1.03 \mathrm{~V}$ at a glassy carbon electrode when the water content was changed from $1 \mathrm{wt} \%$ to $12 \mathrm{wt} \%$, similar to the range considered in this work. These results suggest that, with respect to the electrochemical window, ethaline is much more tolerant to water than reline. In the absence of water, the anodic and cathodic limits are attributed to the reduction of the choline cation and the oxidation of $\mathrm{Cl}^{-}$to $\mathrm{Cl}_{2}$, respectively $[8,10,36]$. With added water, many other reactions are possible [10] and the situation for reline seems particularly complex [36]. It should be noted that even though conventional RTILs can have very large (e.g. 4 - 5 V) electrochemical windows, this can be significantly reduced by the presence relatively low concentrations of water $[1,3]$. As an example, $\left[\mathrm{C}_{4} \mathrm{~min}\right]\left[\mathrm{BF}_{4}\right]$ has a window of $4.6 \mathrm{~V}$ at $0.01 \mathrm{wt} \%$ of $\mathrm{H}_{2} \mathrm{O}$ but this is reduced to $2.4 \mathrm{~V}$ at $0.5 \mathrm{wt} \%$ [37].

\subsection{Effect of Water on Limiting Current and Diffusion Coefficients}

In order to understand the effect of water addition on the mass transport characteristics of the copper-ethaline system, linear polarisation experiments at a RDE were performed. Fig. 5 shows the steady-state voltammogram obtained for $0.20 \mathrm{M} \mathrm{CuCl}_{2} .2 \mathrm{H}_{2} \mathrm{O}$ in ethaline at rotating $\mathrm{Pt}$ disk electrode $(\omega=700 \mathrm{rpm})$ at $25{ }^{\circ} \mathrm{C}$ with increasing amounts of water. Two limiting current plateaux, $i_{\lim 1}$ and $i_{\lim 2}$, are observed corresponding to the step-wise reduction of $\mathrm{Cu}(\mathrm{II})$ complexes to $\mathrm{Cu}(\mathrm{I})$ and $\mathrm{Cu}(\mathrm{I})$ complexes to $\mathrm{Cu}(0)$. Such behaviour has been noted in a number 
of earlier studies, and is similar to that reported for $\mathrm{CuCl}_{2}$ in high chloride aqueous systems. As discussed earlier, the dominant $\mathrm{Cu}$ (II) species is the complex $\left[\mathrm{CuCl}_{4}\right]^{2-}$. For the $\mathrm{Cu}(\mathrm{I})$ chloro-complex, EXAFS [26] and UV-Vis [11,20] studies indicate the predominant electroactive species is $\left[\mathrm{CuCl}_{2}\right]^{-}$but $\left[\mathrm{CuCl}_{3}\right]^{2-}$ may also be present. The overall electrodeposition process can then be written as:

$$
\begin{aligned}
& \mathrm{CuCl}_{4}{ }^{2-}+\mathrm{e}-\Leftrightarrow \mathrm{CuCl}_{2}^{-}+2 \mathrm{Cl}^{-} \\
& \mathrm{CuCl}_{2}{ }^{-}+\mathrm{e}^{-} \Leftrightarrow \mathrm{Cu}+2 \mathrm{Cl}^{-}
\end{aligned}
$$

Fig. 5 indicates that the addition of water increases the limiting current density for the reduction of both the $\mathrm{Cu}(\mathrm{II})$ and $\mathrm{Cu}(\mathrm{I})$ complexes. Previous studies $[20,21]$ have reported a similar effect in relation to comproportionation reactions in the $\mathrm{Cu}$-ethaline system. The limiting currents ( $i_{\mathrm{lim} 1}$ and $i_{\mathrm{lim} 2}$ ) obtained from these plots are summarised in Table 1 . Note that the value of $i_{\mathrm{lim} 2}$ is obtained by subtracting $i_{\mathrm{lim} 1}$ from the overall current.

These results clearly show that the inclusion of water facilitates the transport of the electroactive species, $\left[\mathrm{CuCl}_{4}\right]^{2-}$ and $\left[\mathrm{CuCl}_{2}\right]^{-}$. Using this limiting current data, the diffusion coefficient, $D$, of the copper-chloro complexes can be calculated from the Levich equation:

$$
i_{\lim }=0.62 n F D^{2 / 3} v^{-1 / 6} c \omega^{1 / 2}
$$

where $n$ is the number of transferred electrons, $F$ is the Faraday constant $\left(\mathrm{F} \mathrm{mol}^{-1}\right), D$ is the diffusion coefficient $\left(\mathrm{cm}^{2} \mathrm{~s}^{-1}\right), v$ is the kinematic viscosity $\left(\mathrm{cm}^{2} \mathrm{~s}^{-1}\right), c$ is the concentration of the $\mathrm{Cu}$ complex $\left(\mathrm{mol} \mathrm{cm}^{-3}\right)$ and $\omega$ is the rotation speed $\left(\mathrm{rad} \mathrm{s}^{-1}\right)$. The values for diffusivity of the two copper complexes as a function of water content are summarised in Table 1. As a comparison the measured values at low water content $(1 \mathrm{wt} \%)$ are compared with earlier measurements $[11,22,38,39]$ in ethaline (Table 2 ). It can be seen that there is generally a good agreement between the various $D$ values reported. Notably, the values obtained for $\mathrm{Cu}(\mathrm{II})$ and 
$\mathrm{Cu}(\mathrm{I})$ complexes in aqueous chloride solutions [40] are more than 20 times higher than those obtained in ethaline at the same temperature.

The simplest explanation for the observed increase in diffusivity relates to the corresponding reduction in viscosity with water additions, as described by the Stokes-Einstein relationship $[14,22]$. If this relationship holds, then a plot of $D$ versus inverse of viscosity, fluidity $\left(\eta^{-1}\right)$, should be linear at constant temperature with a slope reflecting the hydrodynamic radius of the species. Fig. 6 suggests that, for both the $\mathrm{Cu}(\mathrm{I})$ and $\mathrm{Cu}(\mathrm{II})$ complexes, diffusion is Stokesian at all water contents. This is in agreement with the results of Al-Murshedi [35] and Su [20] who observed that $\left[\mathrm{CuCl}_{4}\right]^{2-}$ and $\left[\mathrm{FeCl}_{4}\right]^{-}$species in ethaline obey the Stokes-Einstein relationships up to a water content of approximately $50 \mathrm{wt} \%$.

\subsection{Effect of Water on Electrode Kinetics}

As noted previously, apart from the effect of water on the physiochemical properties, it is also important to ascertain the effect of increasing hydration on the kinetics of the electrochemical reactions since this has a fundamental influence on deposit characteristics such as uniformity and morphology. While there are many qualitative studies [16-20] of the effect of water on voltammetric behaviour of type-III eutectics containing a quaternary ammonium salt and a hydrogen bond donor, there are no quantitative electro-kinetic studies. The kinetic studies currently available $[11,39,41,42]$ are focused on the $\mathrm{Cu}(\mathrm{II}) / \mathrm{Cu}(\mathrm{I})$ reaction in ethaline or reline with low water contents. Surprisingly, the kinetics of $\mathrm{Cu}(\mathrm{I}) / \mathrm{Cu}(0)$ reaction step remains unexplored even though this should govern deposit thickness and influence electrocrystallisation. 
Inspection of the voltammograms in Fig. 5 indicate that, in addition to changing the limiting current, increasing water content also alters the overall shape and position of the two voltammetric waves. The half-wave potentials for the $\mathrm{Cu}(\mathrm{II}) / \mathrm{Cu}(\mathrm{I})$ and $\mathrm{Cu}(\mathrm{I}) / \mathrm{Cu}(0)$ couples both shift to more anodic potentials with increased hydration, and the wave shape also appears to be more reversible. Such variations reflect changes in the formal potential and kinetic parameters for the two redox couples. These changes do not arise from ohmic effects since IR compensation was performed during these measurements. Cyclic voltammetry studies $[19,20]$ of ethaline solution containing cupric chloride salts with varying water content have shown similar trends.

In order to assess the electrochemical kinetics more quantitatively, a Koutechy-Levich (K-L) analysis $[11,41,42]$ was performed on both the $\mathrm{Cu}(\mathrm{II}) / \mathrm{Cu}(\mathrm{I})$ and $\mathrm{Cu}(\mathrm{I}) / \mathrm{Cu}(0)$ redox couples. This allows evaluation of both the standard rate constant, $k^{0}$, and the cathodic transfer coefficient, $\alpha_{c}$ for both reactions. These experiments were performed using a Pt RDE at a scan rate of $5 \mathrm{mV} \mathrm{s}^{-1}$ and with rotation speeds from $700-2800 \mathrm{rpm}$ and with $80 \%$ ohmic compensation. The K-L plots (i.e. $i^{-1}$ versus $\omega^{-1 / 2}$ ) were constructed for each potential, $E$, corresponding to the descending part of the wave (e.g. 30 - $80 \%$ of the limiting current). The kinetic currents, $i_{\mathrm{k}}$, were extracted from the intercept of the K-L plots (Fig. 7) and they are related to the potential-dependent rate constant, as follows:

$$
i_{\mathrm{k}}=n F k_{\mathrm{f}}(E) c
$$

where $i_{\mathrm{k}}$ is the kinetic current, $k_{\mathrm{f}}(E)$ is the potential-dependent rate constant and where the other terms have been defined previously. Thereafter, the standard rate constant and the charge transfer coefficient, $\alpha$, of the $\mathrm{Cu}(\mathrm{II}) / \mathrm{Cu}(\mathrm{I})$ and $\mathrm{Cu}(\mathrm{I}) / \mathrm{Cu}(0)$ reactions were estimated from the intercept and the slope of a plot of $\ln k_{\mathrm{f}}(E)$ versus $E-E^{0^{\prime}}$ using the expression: 


$$
\ln k_{\mathrm{f}}(E)=\ln k^{0}-\alpha n F\left(E-E^{\mathrm{o} \prime}\right) / R T
$$

where $E^{0}$ is the formal potential $(\mathrm{V}), k^{0}$ is the standard heterogeneous rate constant $\left(\mathrm{cm} \mathrm{s}^{-1}\right), R$ is the gas constant $\left(\mathrm{J} \mathrm{K}^{-1} \mathrm{~mol}^{-1}\right)$ and $T$ is the absolute temperature $(\mathrm{K})$.

To determine $k^{0}$ it is necessary to know the formal potential for each reaction. While previous studies [11,39] of the $\mathrm{Cu}(\mathrm{II}) / \mathrm{Cu}(\mathrm{I})$ reaction in ethaline is quasi-reversible, the reaction is sufficiently fast, such that $E^{0^{\prime}}$ can be approximated by the half-wave potential, $E_{1 / 2}$. These values are summarised in Table 1 . However, for the $\mathrm{Cu}(\mathrm{I}) / \mathrm{Cu}(0)$ reaction the degree of reversibility was unknown and therefore, in separate experiments, the rest potential of a copper RDE was measured as a function of the concentration of $\left[\mathrm{CuCl}_{2}^{-}\right]$and $\mathrm{Cl}^{-}$. By applying the Nernst equation to reaction (3) it was then possible to estimate $E^{0^{\prime}}$ at each water content and these values have also been tabulated in Table 1.

The kinetic data extracted from K-L analysis is summarised in Table 3, which shows the data obtained at $1 \mathrm{wt} \% \mathrm{H}_{2} \mathrm{O}$ against previously reported values for $\mathrm{Pt}$ and $\mathrm{GC}$ electrodes in ethaline $[11,39,42]$, reline $[41]$ and aqueous chloride systems $[43,44]$. The results in ethaline and reline are in good agreement and values of $\alpha_{\mathrm{c}} \approx 0.3-0.4$ and $k^{0} \approx 10^{-3} \mathrm{~cm} \mathrm{~s}^{-1}$ are typically obtained for the $\mathrm{Cu}(\mathrm{II}) / \mathrm{Cu}(\mathrm{I})$ couple. In comparison, the aqueous chloride solutions tend to have higher values for the transfer coefficient $\left(\alpha_{c}=0.5\right)$ but the rate constants are similar in magnitude $\left(k^{0}\right.$ $\approx 10^{-3} \mathrm{~cm} \mathrm{~s}^{-1}$ ) to the DES systems.

For the $\mathrm{Cu}(\mathrm{I}) / \mathrm{Cu}(0)$ redox couple in ethaline, values of $\alpha_{\mathrm{c}} \approx 0.4$ and $k^{0} \approx 10^{-6} \mathrm{~cm} \mathrm{~s}^{-1}$ were obtained indicating that this step is much more irreversible than the $\mathrm{Cu}(\mathrm{II}) / \mathrm{Cu}(\mathrm{I})$ couple. The only other data reported [11] for the $\mathrm{Cu}(\mathrm{I}) / \mathrm{Cu}(0)$ redox couple in ethaline indicates a much higher value of $k^{0}=10^{-3} \mathrm{~cm} \mathrm{~s}^{-1}$, suggesting quasi-reversible behaviour. However, in that study 
the 'onset' potential [45] rather than the formal potential was used to determine $k^{0}$. The onset potential has a value that is $0.20 \mathrm{~V}$ more cathodic than the actual $E^{0}$ and this makes the reaction appear reversible. For the quasi-reversible $\mathrm{Cu}(\mathrm{II}) / \mathrm{Cu}(\mathrm{I})$ couple, the formal and onset potential are similar and this assumption does not lead to significant differences.

A more recent determination [46] of the $\mathrm{Cu}(\mathrm{II}) / \mathrm{Cu}(\mathrm{I})$ kinetics in ethaline resulted in values of $\alpha_{c}=0.50$ and $k^{0} \approx 10^{-4} \mathrm{~cm} \mathrm{~s}^{-1}$. The authors noted that the value of $\alpha_{\mathrm{c}}$ is in agreement with aqueous values (Table 3) and suggests a symmetric energy barrier for charge transfer. Moreover, they proposed that experimental artefacts in DES systems arising from uncompensated solution resistance and an uneven current distribution could result in inaccurate or low values for $\alpha_{c}$. However, the majority of earlier studies $[39,42]$ as well as this work has used IR compensation, so this is not a plausible explanation for the low values of $\alpha_{c}$. An uneven current distribution arising from poorly conducting DES systems can also lead to errors in the determination of kinetic parameters [46]. This problem was studied theoretically by West and Newman [47] at rotating disk electrodes and appropriate correction terms were developed for $k^{0}$ and $\alpha$ based on the Wagner number, $W_{\mathrm{a}}$. Using their methodology and assuming a typical value of $W_{\mathrm{a}} \approx 0.1$ (Table 4) the correction for $k^{0}$ is estimated to be $<10 \%$ and for $\alpha_{\mathrm{c}}<15 \%$, showing that the error in kinetic parameters due to the uneven current distribution are small.

The dependence of the kinetic parameters $\left(\alpha_{c}\right.$ and $\left.k^{0}\right)$ on water content is shown in Fig. 8 and 9. Fig. 8 shows that there is a general increase in $k^{0}$ for both redox couples with water content and the values observed at $15 \mathrm{wt} \%$ are nearly an order of magnitude greater than at $1 \mathrm{wt} \%$. Note that for all water contents the $\mathrm{Cu}(\mathrm{II}) / \mathrm{Cu}(\mathrm{I})$ couple is much faster than the $\mathrm{Cu}(\mathrm{I}) / \mathrm{Cu}(0)$ couple. The dependence of the transfer coefficient for both redox couples is shown in Fig. 9. 
for the $\mathrm{Cu}(\mathrm{I}) / \mathrm{Cu}(0)$ reaction there appears to be a slight overall increase in $\alpha_{c}$ with hydration.

Note that the value of $\alpha_{c}$ obtained for both redox couples at $6 \mathrm{wt} \%$ appears anomalously high, with a much large associated error than at other water concentrations.

The complexities of water-containing RTIL and DES systems make it difficult to provide a definitive explanation of the observed dependencies of the kinetic parameters on water content, but some possibilities are discussed below. An additional complication is that reactions (2) and (2) may not be elementary, so that the $\alpha$ values reflect not only changes in the symmetry factor, $\beta$, but also changes in mechanism. However, a simple kinetic analysis [48] indicates that, as long as the charge transfer steps are rate determining, then $\alpha_{c}=\beta$, regardless of any preceding or following chemical steps (e.g. loss of chloride ligands). For this reason, we can assume that any changes in the measured cathodic transfer coefficient reflect something fundamental about the charge transfer process itself.

For example, if there were a change in the speciation of the $\mathrm{Cu}(\mathrm{I})$ and $\mathrm{Cu}(\mathrm{II})$ complexes then this might lead to very different kinetic behaviour. It has already been shown that water addition to a EMI-DCA ionic liquid increased the reversibility of the $\mathrm{Zn}(\mathrm{II}) / \mathrm{Zn}$ couple and this was attributed [49] to $\mathrm{H}_{2} \mathrm{O}$ replacing $\mathrm{DCA}^{-}$ligands in the $\mathrm{Zn}(\mathrm{DCA})_{n}{ }^{(n-2)-}$ complex. However, it has already been shown that changes in $\mathrm{Cu}$ (II) speciation in ethaline typically require much higher water contents than employed here. Another possible effect relates to the effect on viscosity on the rate of charge transfer reactions at electrodes. According to Marcus theory, $k^{0}$ should increase with solvent fluidity for an outer sphere reaction, and this has been demonstrated for ferrocene in RTILs over a wide range of viscosities [50]. However, the reduction of the $\mathrm{CuCl}_{4}{ }^{2-}$ is not a simple outer sphere reaction and the second step involving the reduction of $\mathrm{CuCl}_{2}{ }^{-}$is 
best described as an ion-transfer reaction. Nevertheless, it is interesting that both reactions show an increase in $k^{0}$ with increasing fluidity.

The kinetic parameters are also very sensitive to the double layer structure and conditions at the electrode-solution interface. The double layer structure of RTILs and DES is inherently different from aqueous systems, and it is believed [2,51] that it consists of alternate layers of anions and cations. In some RTILs the effect of hydration is to solvate ionic species and the layered structure gradually breaks down into something resembling a more conventional GouyChapman-Stern double layer [52]. In DES systems, this effect is not observed, but in the presence of water and an applied potential there is a similar disruption of the layered structure [53]. It is possible that such effects could alter the energy barrier for charge transfer (or change its symmetry) which would manifest itself in changes to $k^{0}$ and $\alpha$.

\subsection{Effect of Water on the Current Distribution}

As previously noted, one of the major objectives of this study is to determine if the inclusion of water can improve the throwing power (thickness uniformity) of the deposit. The current distribution can be conveniently assessed in terms of a dimensionless parameter, called the Wagner number, $W_{\mathrm{a}}$, which defines the ratio of the polarisation resistance to the ohmic resistance [54]. At high polarisation (i.e. in the Tafel region), the Wagner number can be defined by:

$$
W_{\mathrm{a}}=\frac{R T \kappa}{\alpha_{\mathrm{c}} F i_{\mathrm{avg}} r_{0}}
$$

where $i_{\text {avg }}$ is the average current density, $r_{0}$ is the radius of the disc. A primary current distribution corresponds to $W_{\mathrm{a}} \rightarrow 0$, while a secondary current distribution corresponds to $W_{\mathrm{a}}$ $>0$. A high value of $W_{\mathrm{a}}$ is indicative of good thickness uniformity, and Eq. 7 indicates that this 
can be achieved at a low value of $\alpha$ (i.e. a high Tafel slope), a high value of $\kappa$ and a low $i_{\text {avg. }}$. Using the values of $\alpha$ and $\kappa$ obtained earlier, we can therefore estimate $W_{\mathrm{a}}$ under typical plating conditions and make a preliminary assessment of the thickness uniformity.

Table 4 show the Wagner numbers calculated for each water-containing DES using the relevant kinetic and conductivity and data. The kinetic data for the $\mathrm{Cu}(\mathrm{I}) / \mathrm{Cu}(0)$ couple is used for this calculation, and it is also assumed that $i_{\text {avg }}$ corresponds to $80 \%$ of the total limiting current (i.e. $\left.i_{\text {avg }}=0.8 \times i_{\text {lim }}\right)$. The data in Table 4 indicates that the Wagner numbers for water-containing ethaline range from $W_{\mathrm{a}}=0.17\left(1 \mathrm{wt} \% \mathrm{H}_{2} \mathrm{O}\right)$ to $W_{\mathrm{a}}=0.08\left(15 \mathrm{wt} \% \mathrm{H}_{2} \mathrm{O}\right)$. These low values for $W_{\mathrm{a}}$ indicates a near primary (uneven) current distribution will exist at the electrode. The effect of added water appears to make the current distribution slightly worse because $i_{\text {lim }}$ and therefore $i_{\text {avg }}$ increases with water content.

In order to verify these calculations, the thickness distribution of the electrodeposited copper layer was measured at $1 \mathrm{wt} \%, 6 \mathrm{wt} \%$ and $10 \mathrm{wt} \% \mathrm{H}_{2} \mathrm{O}$. Fig. 10, for example, shows the copper thickness variation by SEM as a function of the radial position in a DES electrolyte containing $1 \mathrm{wt} \%$ and $6 \mathrm{wt} \% \mathrm{H}_{2} \mathrm{O}$. As expected, the thickness increases from centre to edge, but near the disk edge the limiting current is exceeded and the deposit becomes dendritic. Note that because additives (e.g. brighteners or levellers) were not used, the surface roughness is comparatively high even when the limiting current is not exceeded. The thickness variations are shown more clearly in Fig. 11. As a comparison, the theoretical primary current distribution for a recessed RDE is plotted on the graph [55]. This line corresponds to an aspect ratio of $d / r=0.20$ for the recess, where $d$ is the recess depth.

For all water contents, the current distribution is similar or slightly more uniform than that expected if a purely primary current distribution prevailed. This slight improvement in 
uniformity reflects that the current distribution has some secondary character $\left(W_{\mathrm{a}}>0\right)$ in the DES systems (Table 4). However, given the relatively small changes in $W_{\mathrm{a}}$ with water content and the fairly large experimental errors in the thickness measurements, the agreement between the theory and experiments is reasonable. However, our calculations show that large changes in water content results in relatively small changes in $W_{\mathrm{a}}$, which means that the thickness profile across the disc is always close to primary. Effectively, as $W_{\mathrm{a}} \propto \kappa / i_{\text {avg, }}$ the improvement in conductivity is compensating for the increase in the overall plating rate.

Based on these findings, for the copper-ethaline systems there appears to be no obvious disadvantage in using water as a co-solvent. However, due to the effect it can have on physicochemical characteristics and kinetics, it is important that the water content be monitored in order to have a reproducible and stable electrodeposition process. In some cases, especially when electronegative metals such as $\mathrm{Zn}, \mathrm{Cr}$ or $\mathrm{Ni}$ are being deposited, co-reduction of water may result in a loss of current efficiency or the formation of surface oxides. For these reasons, the use of hydrated RTIL and DES systems should be carefully considered based on deposit requirements.

\section{Conclusions}

This study has shown that the addition of water to type-III eutectics comprising ethaline and a hydrated cupric salt significantly improves their physiochemical and electrochemical properties and this could be exploited in electrodeposition applications. For example, the viscosity and resistivity of the DES systems substantially decreased with added water in the range 1 - $15 \mathrm{wt} \%$. Importantly, water additions did not greatly influence the speciation, and the dominant electroactive species is $\left[\mathrm{CuCl}_{4}\right]^{2-}$ for water contents up to $35 \mathrm{wt} \%$. Similarly, the electrochemical window of ethaline was not substantially reduced by water additions up to 15 
wt\%. This is in contrast to the reline DES and other RTILs whose windows are typically more sensitive to water contamination.

In order to assess the effect of water on the mass transport characteristics or the $\mathrm{Cu}$-ethaline system, polarisation measurements were performed at a rotating disc electrode. The limiting current for the reduction of the $\mathrm{Cu}$ (II) and $\mathrm{Cu}(\mathrm{I})$ chloro-complexes increased with water additions reflecting an increased diffusivity of the species. The improvement in diffusivity could be directly attributed to the reduction in DES viscosity associated with increasing hydration. These experimental findings indicated that the inclusion of water enhances transport, and should therefore facilitate higher deposition rates.

The effect of water on the electrochemical kinetics of the $\mathrm{Cu}(\mathrm{II})$ and $\mathrm{Cu}(\mathrm{I})$ chloro-complexes was studied. The reduction of $\mathrm{Cu}(\mathrm{I})$ complexes was of particular interest as its kinetics have an important influence on both electrocrystallisation and the current distribution. These measurements indicated that, the reduction of the $\mathrm{Cu}$ (II) chloro-complexes is quasi-reversible, while the $\mathrm{Cu}(\mathrm{I})$ complex behaves irreversibly. The measured kinetic parameters obtained in the absence of water were generally in agreement with previous values obtained in ethaline and reline. The kinetics of both reactions were accelerated by water addition, although the transfer coefficients were relatively unchanged.

The kinetic and conductivity data also predict a slight improvement in the Wagner number with increasing water content indicating possible improvements in the thickness distribution. While experimental studies of the thickness distribution indicated relatively modest improvements with water addition, they did allow a higher deposition rate, while mitigating against the degradation in the thickness uniformity that would normally occur under these conditions. Collectively the results suggest that water addition could improve the deposition rates while maintaining deposit uniformity. 


\section{Acknowledgements}

P. Valverde would like to acknowledge the Secretariat of Higher Education, Science, Technology, and Innovation of Ecuador (SENESCYT) for funding this work. 


\section{References}

1. Endres F, Abbott A, MacFarlane D (2017) Electrodeposition from ionic liquids, 2nd edn. Wiley-VCH, Germany.

2. Abbott AP, Frisch G, Ryder KS (2013) Electroplating using ionic liquids. Annu Rev Mater Res 43:335-358. https://doi.org/10.1146/annurev-matsci-071312-121640

3. Abbott AP, McKenzie KJ (2006) Application of ionic liquids to the electrodeposition of metals. Phys Chem Chem Phys 8:4265-4279. https://doi.org/10.1039/b607329h

4. Abbott AP, Capper G, Davies DL, Rasheed R, Tambyrajah V (2003) Novel solvent properties of choline chloride/urea mixtures. Chem Commun 9:70-71. https://doi.org/10.1039/b210714g

5. Smith EL, Abbott AP, Ryder KS (2014) Deep eutectic solvents (DESs) and their applications. Chem Rev 114:11060-11082. https://doi.org/10.1021/cr300162p

6. Tome LIN, Baiao V, da Silva W, Brett CMA (2018) Deep eutectic solvents for the production and application of new materials. Appl Mater Today 10:30-50. https://doi.org/10.1016/j.apmt.2017.11.005

7. Abbott AP, Ryder KS, Konig U (2013) Electrofinishing of metals using eutectic based ionic liquids. Trans IMF 86:196-204. https://doi.org/10.1179/174591908X327590

8. Du C, Zhao B, Chen XB, Birbilis N, Yang H (2016) Effect of water presence on choline chloride-2 urea ionic liquid and coating platings from the hydrated ionic liquid. Sci Rep 6:29255. https://doi.org/10.1038/srep29225

9. Valverde PE, Green TA, Roy S (2017) Copper electrodeposition from a water-containing choline chloride based deep eutectic solvent. ECS Trans 77:859-864. https://doi.org/10.1149/07711.0859ecst 
10. Haerens K, Matthijs E, Binnemans K, Van der Bruggen B (2009) Electrochemical decomposition of choline chloride based ionic liquid analogues. Green Chem 11:1357-1365. https://doi.org/10.1039/b906318h

11. Mandroyan A, Mourad-Mahmoud M, Doche ML, Hihn JY (2014) Effects of ultrasound and temperature on copper electro reduction in deep eutectic solvents (DESs). Ultrason Sonochem 21:2010-2019. https://doi.org/10.1016/j.ultsonch.2014.02.019

12. Pollet BG, Hihn JY, Mason TJ (2008) Sono-electrodeposition (20 and $850 \mathrm{kHz}$ ) of copper in aqueous and deep eutectic solvents. Electrochim Acta 53:4248-4256. https://doi.org/10.1016/j.electacta.2007.12.059

13. Hussey CL (2014) Molten salts and ionic liquids: where have we been and where are we going? An electrochemist's perspective. ECS Trans 64:3-5. https://doi.org/10.1149/06404.0003ecst

14. D’Agostino C, Gladden LF, Mantle MD, Abbott AP, Ahmed EI, Al-Murshedi AYM, Harris RC (2015) Molecular and ionic diffusion in aqueous-deep eutectic solvent mixtures: probing inter-molecular interactions using PFG NMR. Phys Chem Chem Phys 17:15297-15304. https://doi.org/10.1039/c5cp01493j

15. Ma C, Laaksonen A, Liu C, Lu X, Ji X (2018) The peculiar effect of water on ionic liquids and deep eutectic solvents. Chem Soc Rev 47:8685-8720. https://doi.org/10.1039/c8cs00325d

16. Protsenko VS, Kityk AA, Shaiderov DA, Danilov FI (2015) Effect of water content on physicochemical properties and electrochemical behavior of ionic liquids containing choline chloride, ethylene glycol and hydrated nickel chloride. J Mol Liq 212:716-722. https://doi.org/10.1016/j.molliq.2015.10.028

17. Cherigui EAM, Sentosun K, Mamme MH, Lukaczynska M, Terryn H, Bals S, Ustarroz J (2018) On the control and effect of water content during the electrodeposition of $\mathrm{Ni}$ 
nanostructures from deep eutectic solvents. J Phys Chem C 122:23129-23142. https://doi.org/10.1021/acs.jpcc.8b05344

18. McCalman DC, Sun L, Zhang Y, Brennecke JF, Maginn EJ, Schneider WF (2015) Speciation, conductivities, diffusivities, and electrochemical reduction as a function of water content in mixtures of hydrated chromium chloride/choline chloride. J Phys Chem B 119:6018-6023. https://doi.org/ 10.1021/acs.jpcb.5b01986

19. De Vreese P, Brooks NR, Van Hecke K, Van Meervelt L, Matthijs E, Binnemans K, Van Deun R (2012) Speciation of copper(II) complexes in an ionic liquid based on choline chloride and in choline chloride/water mixtures. Inorg Chem 51:4972-4981. https://doi.org/10.1021/ic202341m

20. Su Y, Liu J, Wang R, Aisa S, Cao X, Li S, Wang B, Zhou Q (2018) Comproportionation reaction of $\mathrm{Cu}(\mathrm{II}) / \mathrm{Cu}(0)$ in ethaline-water mixed solvents. J Electrochem Soc 165:H78H83. https://doi.org/10.1149/2.1331802jes

21. Green TA, Valverde PE, Roy S (2018) Anodic reactions and the corrosion of copper in deep eutectic solvents. J Electrochem Soc 165:D313-D320. https://doi.org/ $\underline{10.1149 / 2.0371809 \mathrm{jes}}$

22. Abbott AP, El Ttaib K, Frisch G, McKenzie KJ, Ryder KS (2009) Electrodeposition of copper composites from deep eutectic solvents based on choline chloride. Phys Chem Chem Phys 11:4269-4277. https://doi.org/ 10.1039/b817881j

23. Ghosh S, Roy S (2014) Electrochemical copper deposition from an ethaline- $\mathrm{CuCl}_{2} \cdot 2 \mathrm{H}_{2} \mathrm{O}$ DES. Surf Coat Technol 238:165-173. https://doi.org/10.1016/j.surfcoat.2013.10.069

24. Bernasconi R, Zebarjadi M, Magagnin L (2015) Copper electrodeposition from a chloride free deep eutectic solvent. J Electroanal Chem 758:163-169. https://doi.org/10.1016/j.jelechem.2015.10.024 
25. Popescu AM, Constantin V, Cojocaru A, Olteanu M (2011) Electrochemical behaviour of copper (II) chloride in choline chloride-urea deep eutectic solvent. Rev Chim 62:206-211.

26. Hartley JM, Ip CM, Forrest GCH, Singh K, Gurman SJ, Ryder KS, Abbott AP, Frisch G (2014) EXAFS study into the speciation of metal salts dissolved in ionic liquids and deep eutectic solvents. Inorg Chem 53:6280-6288. https://doi.org/10.1021/ic500824r

27. Li G, Camaioni DM, Amonette JE, Zhang ZC, Johnson TJ, Fulton JL (2010) $\left[\mathrm{CuCl}_{\mathrm{n}}\right]^{2-\mathrm{n}}$ ion-pair species in 1-ethyl-3-methylimidazolium chloride ionic liquid-water mixtures: ultraviolet-visible, X-ray absorption fine structure, and density functional theory characterization. J Phys Chem B 114:12614-12622. https://doi.org/10.1021/jp106762b

28. Abbott AP, Ballantyne A, Harris RC, Juma JA, Ryder KS, Forrest G (2015) Choline chloride based ionic liquids containing nickel chloride: physicochemical properties and kinetics of $\mathrm{Ni}(\mathrm{II})$ electroreduction. Electrochim Acta 176:718-726. https://doi.org/10.1016/j.electacta.2017.05.144

29. Miller MA, Wainright JS, Savinell RF (2017) Iron electrodeposition in a deep eutectic solvent for flow batteries. $J$ Electrochem Soc 164:A796-A803. https://doi.org/10.1149/2.1141704jes

30. Danilov, FI, Protsenko VS, Kityk AA, Shaiderov DA, Vasil'eva EA, Kumar UP, Kennady CJ (2017) Electrodeposition of nanocrystalline nickel coatings from a deep eutectic solvent with water addition. Prot Met Phys Chem Surf 53: 1131-1138. https://doi.org/10.1134/S2070205118010203

31. Protsenko VS, Bobrova LS, Danilov FI (2017) Physicochemical properties of ionic liquid mixtures containing choline chloride, chromium (III) chloride and water: effects of temperature and water content. Ionics 23:637-643. https://doi.org/10.1007/s11581-016$\underline{1826-7}$ 
32. Abbott AP, Harris RC, Ryder KS (2007) Application of hole theory to define ionic liquids by their transport properties. J Phys Chem B 111:4910-4913. https://doi.org/ $\underline{10.1021 / j p 0671998}$

33. Shah D, Mjalli FS (2014) Effect of water on the thermo-physical properties of reline. Phys Chem Chem Phys 16:23900-23907. https://doi.org/10.1039/c4cp02600d

34. Hammond OS, Bowron DT, Edler KJ (2017) The effect of water upon deep eutectic solvent nanostructure: an unusual transition from ionic mixture to aqueous solution. Agnew Chem Int 56:9782-9785. https://doi.org/10.1002/anie.201702486

35. Al-Murshedi AYM (2018) Deep eutectic solvent-water mixtures. Dissertation, University of Leicester

36. Bučko M, Roy S, Valverde-Armas P, Onjia A, Bastos AC, Bajat JB (2018) Voltammetric response of water in deep eutectic solvent based on choline chloride and urea. $\mathbf{J}$ Electrochem Soc 165:H1059-H1065. https://doi.org/10.1149/2.0921816jes

37. O’Mahony AM, Silvester DS, Aldous L, Hardacre C, Compton RG (2008) Effect of water on the electrochemical window and potential limits of room-temperature ionic liquids. $\mathbf{J}$ Chem Eng Data 53:2884-2891. https://doi.org/10.1021/je800678e

38. Ghosh S, Ryder K, Roy S (2014) Electrochemical and transport properties of ethaline containing copper and tin chloride. Trans IMF 92:41-46. https://doi.org/10.1179/0020296713Z.000000000133

39. Lloyd D, Vainikka T, Murtomaki L, Kontturi K, Ahlberg E (2011) The kinetics of the $\mathrm{Cu}^{2+} / \mathrm{Cu}^{+}$redox couple in deep eutectic solvents. Electrochim Acta 56:4942-4948. https://doi.org/10.1016/j.electacta.2011.03.133

40. Ponce de Leon C, Walsh FC (2003) Research and development techniques 1: potentiodynamic studies of copper metal deposition. Trans IMF 81:B95-B100. https://doi.org/10.1080/00202967.2003.11871523 
41. Tsuda T, Boyd L, Kuwabata S, Hussey CL (2009) Electrochemistry of copper (I) oxide in the 66.7-33.3 mol \% urea-choline chloride room-temperature eutectic melt. ECS Trans. 16:529-540. https://doi.org/10.1149/1.3159358

42. Lloyd D, Vainikka T, Schmachtel S, Murtomaki K (2013) The development of an all copper hybrid redox flow battery using deep eutectic solvents. Electrochim Acta 69:139145. https://doi.org/10.1016/j.electacta.2013.03.130

43. Kiekens P, Verbeeck RMH, Temmerman E (1981) A kinetic study of the $\mathrm{Cu}(\mathrm{II}) / \mathrm{Cu}(\mathrm{I})$ system in $\mathrm{Cl}^{-}$media at the glassy carbon electrode. Mikrochim Acta 76:29-36. https://doi.org/10.1007/BF01197301

44. Hall DM, LaRow EG, Schatz RS, Beck JR, Lvov SN (2015) Electrochemical kinetics of $\mathrm{CuCl}(\mathrm{aq}) / \mathrm{HCl}(\mathrm{aq})$ electrolyzer for hydrogen production via a $\mathrm{Cu}-\mathrm{Cl}$ thermochemical cycle. J Electrochem Soc 162:F108-F114. https://doi.org/10.1149/2.0661501jes

45. Abbott AP, Frisch G, Gurman SJ, Hillman AR, Hartley J, Holyoak F, Ryder KS (2011) Ionometallurgy: designer redox properties for metal processing. Chem Commun 47:10031- 10033. https://doi.org/10.1039/c1cc13616j

46. Shen D, Steinberg K, Akolkar R (2018) Avoiding pitfalls in the determination of reliable electrochemical kinetics parameters for the $\mathrm{Cu}^{2+} \rightarrow \mathrm{Cu}^{1+}$ reduction reaction in deep eutectic solvents. J Electrochem Soc 165:E808-E815. https://doi.org/10.1149/2.1011814jes

47. West AC, Newman J (1989) Corrections to kinetic measurements taken on a disk electrode. J Electrochem Soc 136:139-143. https://doi.org/10.1149/1.2096573

48. Oldham KB, Myland JC, Bond AM (2011) Electrochemical science and technology: fundamentals and applications, Wiley, United Kingdom, pp 140

49. Xu M, Ivey DG, Qu W, Xie Z (2014) Improved Zn/Zn(II) redox kinetics, reversibility and cyclability in 1-ethyl-3-methylimmidazolium dicyanamide with water and dimethyl 
sulfoxide added. J Power Sources 252:327-323.

https://doi.org/10.1016/j.jpowsour.2013.12.014

50. Bentley CL, Li J, Bond AM, Zhang J (2016) Mass-transport and heterogeneous electrontransfer kinetics associated with the ferrocene/ferrocenium process in ionic liquids. J Phys. Chem C 120:16516-16525. https://doi.org/10.1021/acs.jpcc.6b05545

51. Fedorov MV, Kornyshev AA (2014) Ionic Liquids at Electrified Interfaces. Chem Rev 114:2978-3026. https://doi.org/10.1021/cr400374x

52. Cui T, Lahiri A, Carstens T, Borisenko N, Pulletikurthi G, Kuhl C, Endres F (2016) Influence of water on the electrified ionic liquid/solid interface: a direct observation of the transition from a multilayered structure to a double-layer structure. J Phys Chem C 120:9341-9349. https://doi.org/10.1021/acs.jpcc.6b02549

53. Hammond OS, Lui H, Westermann C, Al-Murshedi AYM, Endres F, Abbott AP, Warr GG, Edler KJ, Atkin R (2019) Nanostructure of the deep eutectic solvent/platinum electrode interface as a function of potential and water content. Nanoscale Horiz 4:158168. https://doi.org/10.1039/c8nh00272j

54. Newman J, Thomas-Alyea KE (2004) Electrochemical systems, 3rd edn. John Wiley \& Sons, USA

55. Dinan TE, Matlosz M, Landolt D (1991) Experimental investigation of the current distribution on a recessed rotating disk electrode. J Electrochem Soc 138:2947-2951. https://doi.org/10.1149/1.2085346 


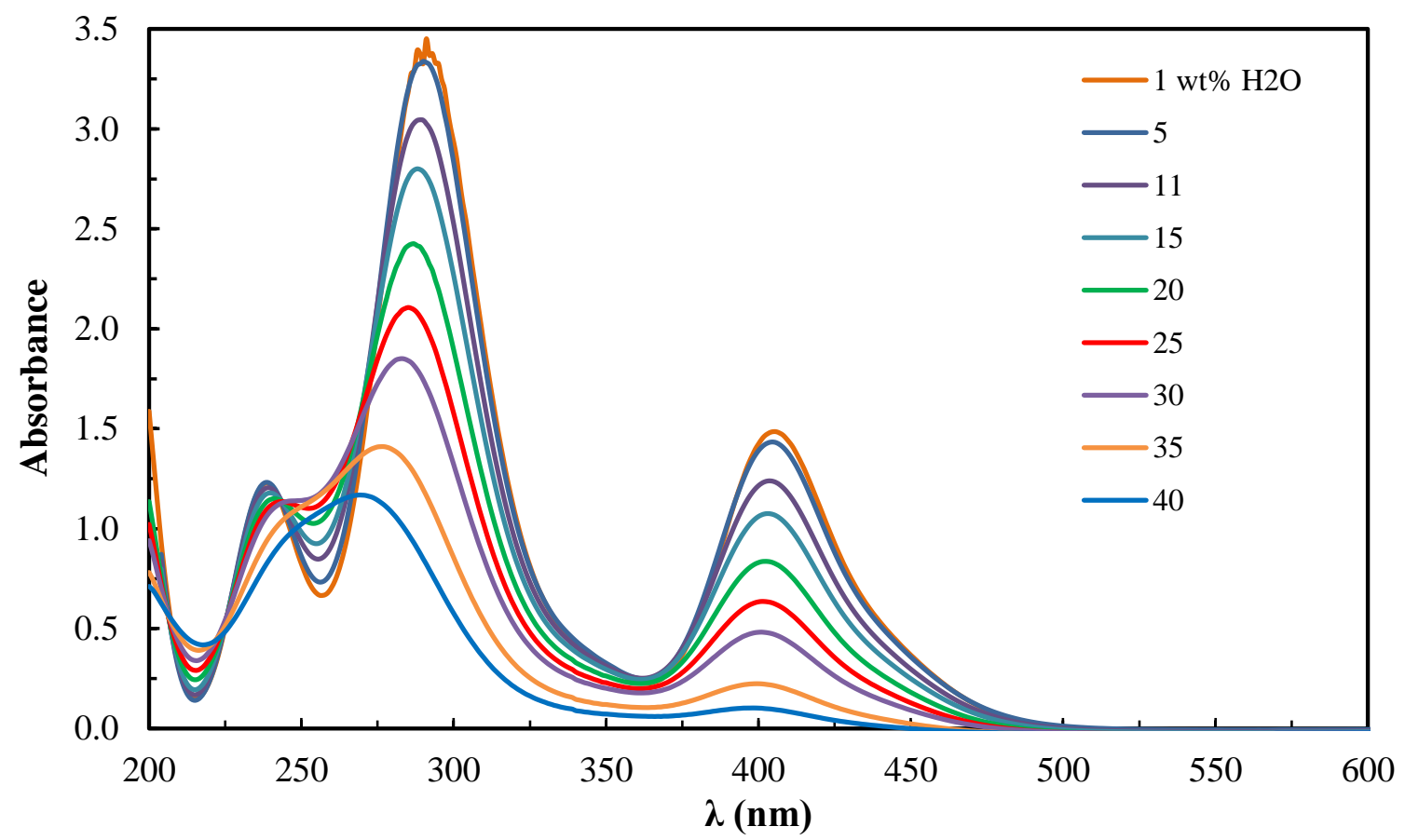

Fig. 1: UV-Vis spectra of $0.05 \mathrm{M} \mathrm{CuCl}_{2} \cdot 2 \mathrm{H}_{2} \mathrm{O}$ in ethaline system at $1-40 \mathrm{wt} \% \mathrm{H}_{2} \mathrm{O}$. The cuvette path length was $125 \mu \mathrm{m}$. 


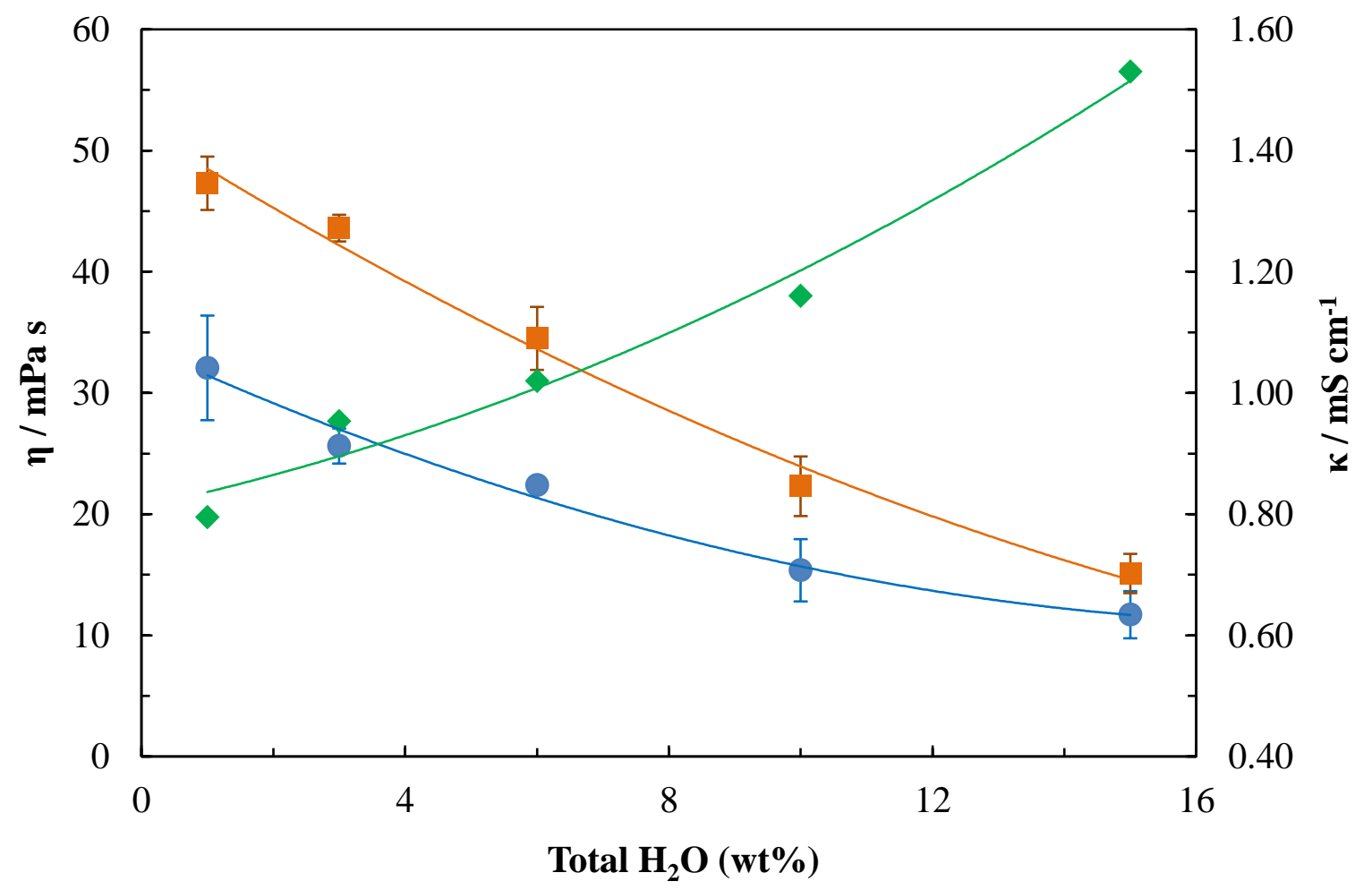

Fig. 2: Viscosity of ethaline (๑) and ethaline containing $0.20 \mathrm{M} \mathrm{CuCl}_{2} \cdot 2 \mathrm{H}_{2} \mathrm{O}(\square)$ as a function of water content $(1-15 \mathrm{wt} \%)$ at $25{ }^{\circ} \mathrm{C}$. Conductivity ( ) as a function of water content in ethaline containing $0.20 \mathrm{M} \mathrm{CuCl}_{2} \cdot 2 \mathrm{H}_{2} \mathrm{O}$ 


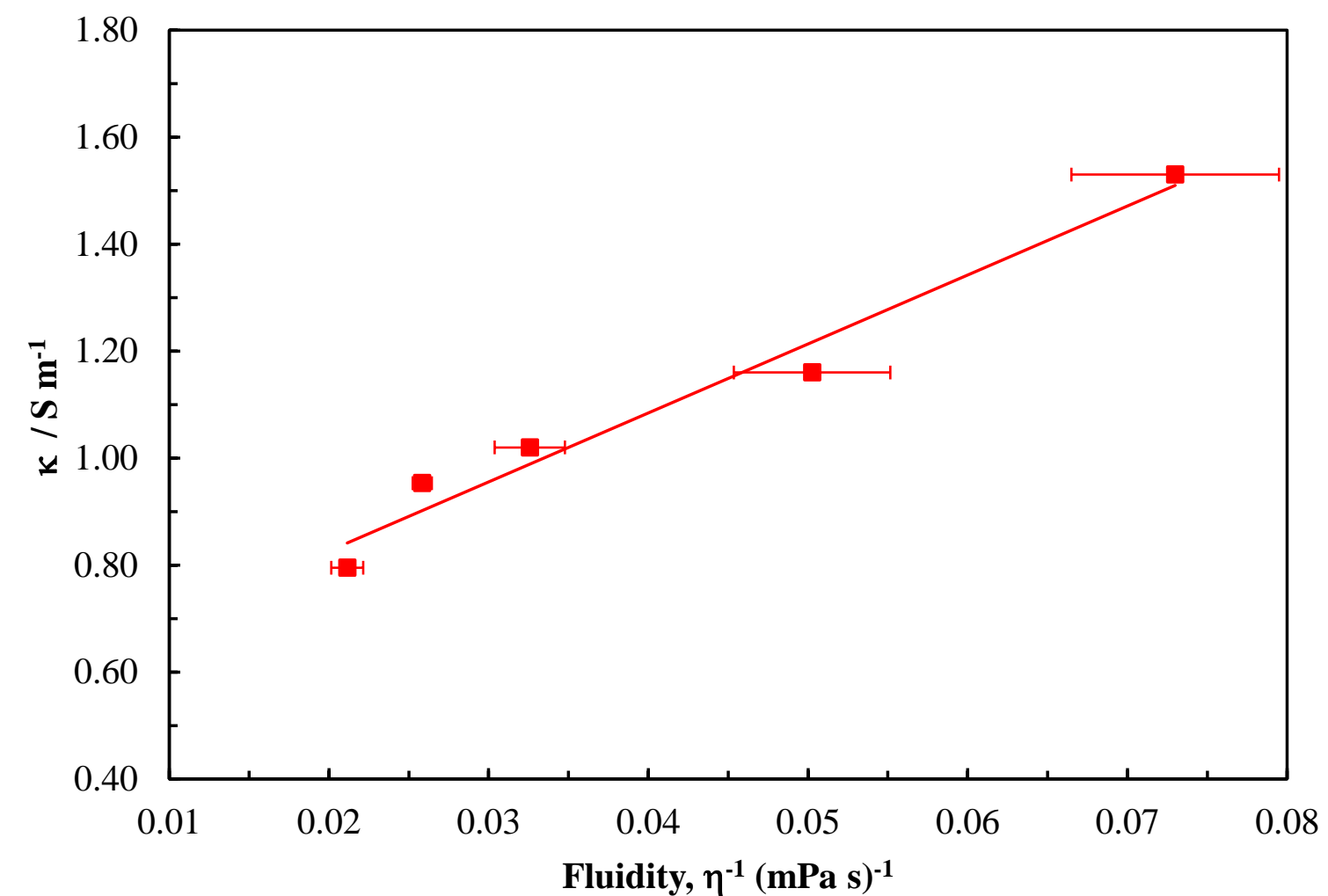

Fig. 3: Dependence of the conductivity, $\kappa$, on fluidity for ethaline containing $0.20 \mathrm{M}$ $\mathrm{CuCl}_{2} \cdot 2 \mathrm{H}_{2} \mathrm{O}$ and various amount of water. 


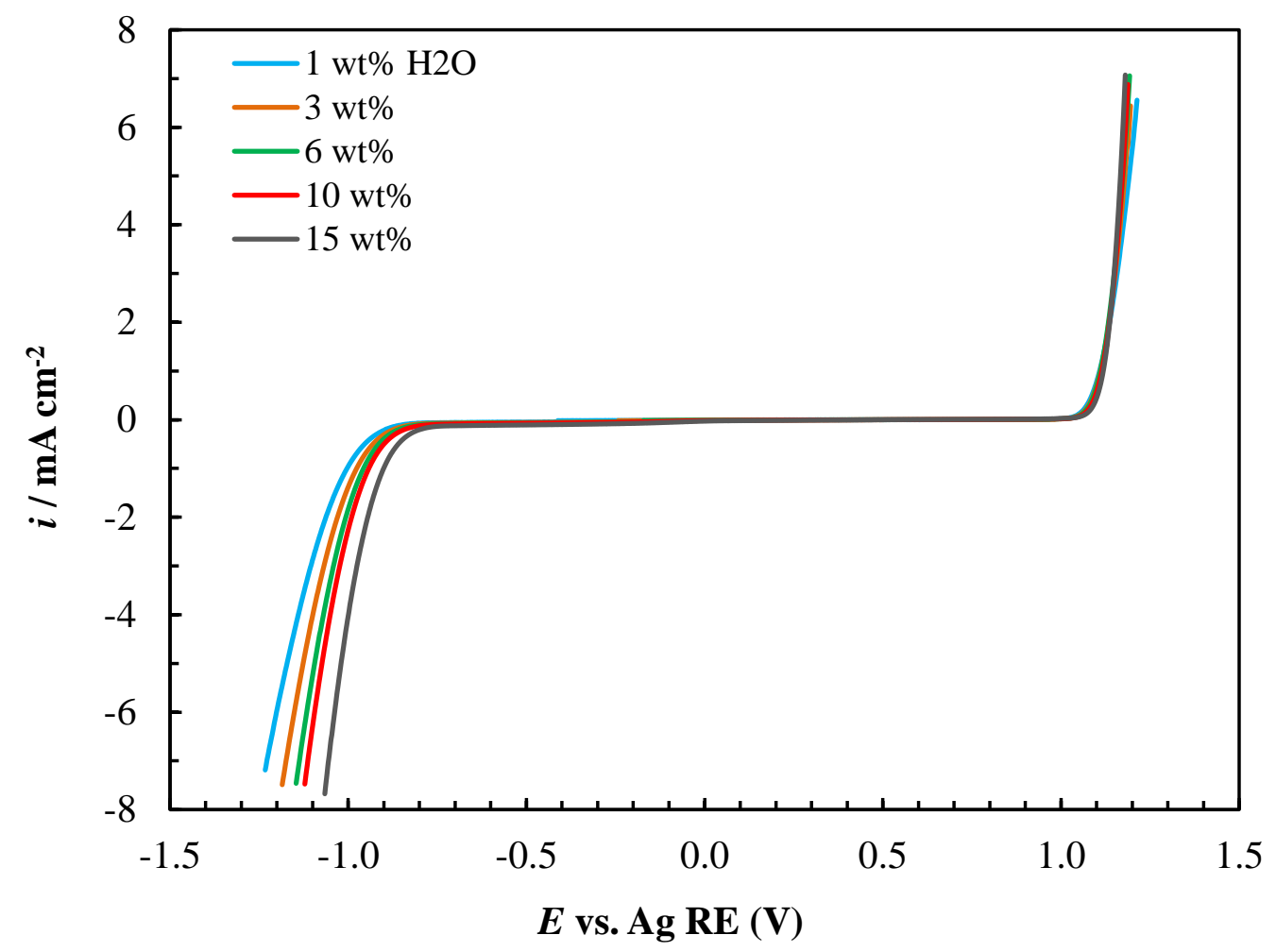

Fig. 4: Determination of the electrochemical window in ethaline at various concentrations of added water. All the experiments were carried out on Pt electrode at $25^{\circ} \mathrm{C}$, using a scan rate of $5 \mathrm{mV} \mathrm{s}^{-1}$ and rotation speed of $700 \mathrm{rpm}$. 


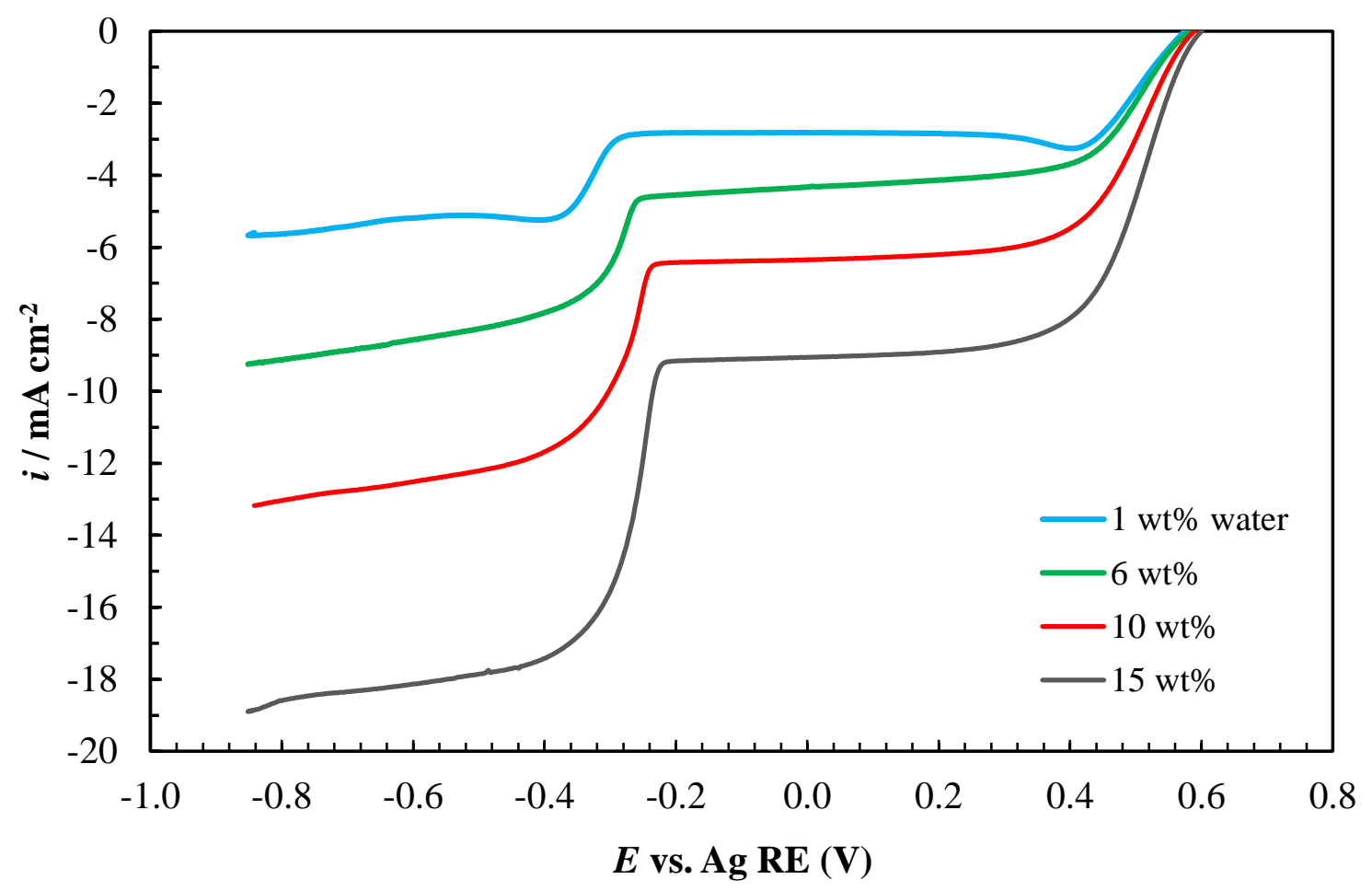

Fig. 5: Steady-state voltammograms for $0.20 \mathrm{M} \mathrm{CuCl}_{2} \cdot 2 \mathrm{H}_{2} \mathrm{O}$ in ethaline as a function of water content. The scan rate was $5 \mathrm{mV} \mathrm{s}^{-1}$ and $\omega=700 \mathrm{rpm}$. 


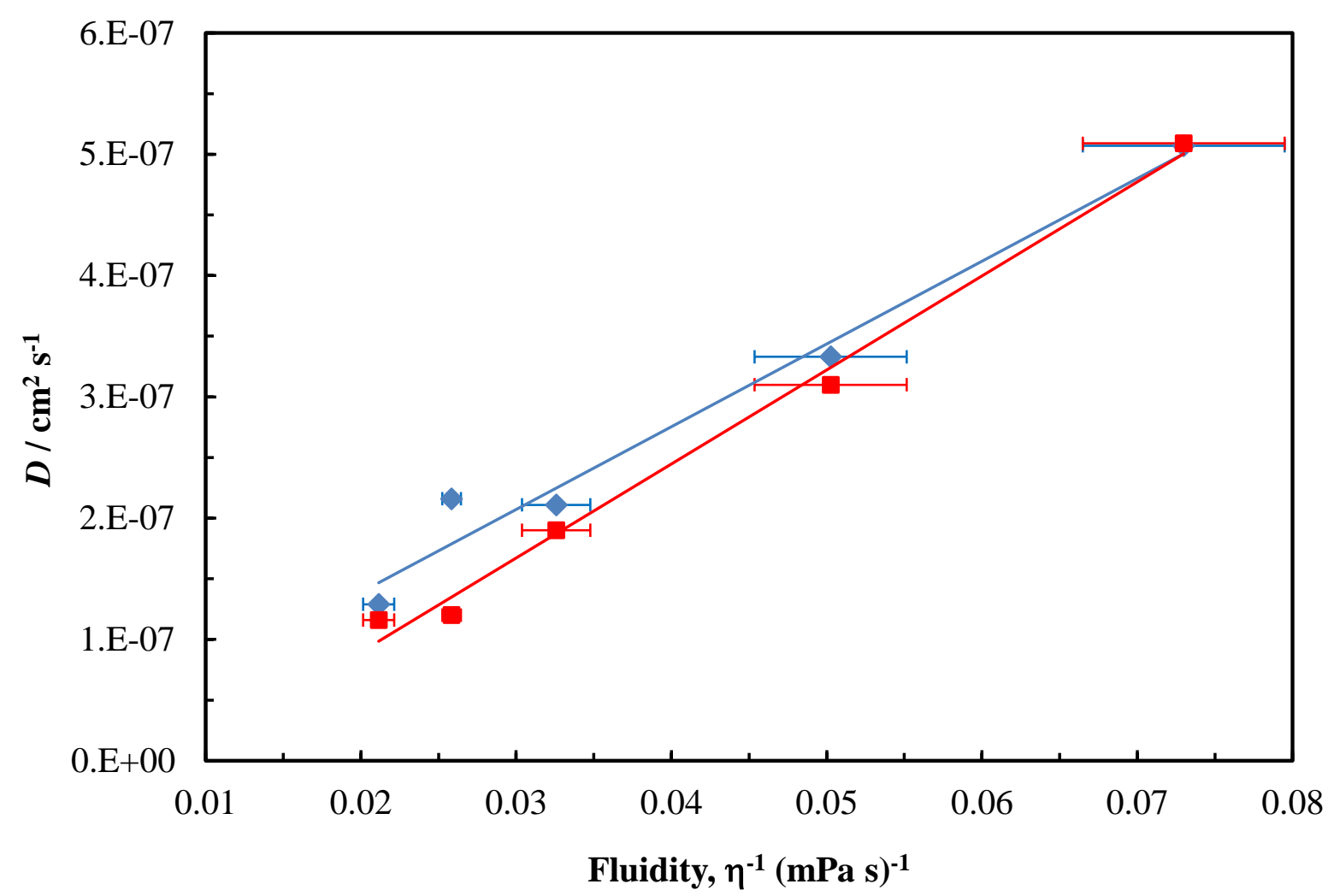

Fig. 6: Dependence of the diffusivity of the $\mathrm{Cu}(\mathrm{I})$ complex $(\diamond)$ and $\mathrm{Cu}(\mathrm{II})$ complex ( $\square$ ) species as the fluidity is increased by water additions. 

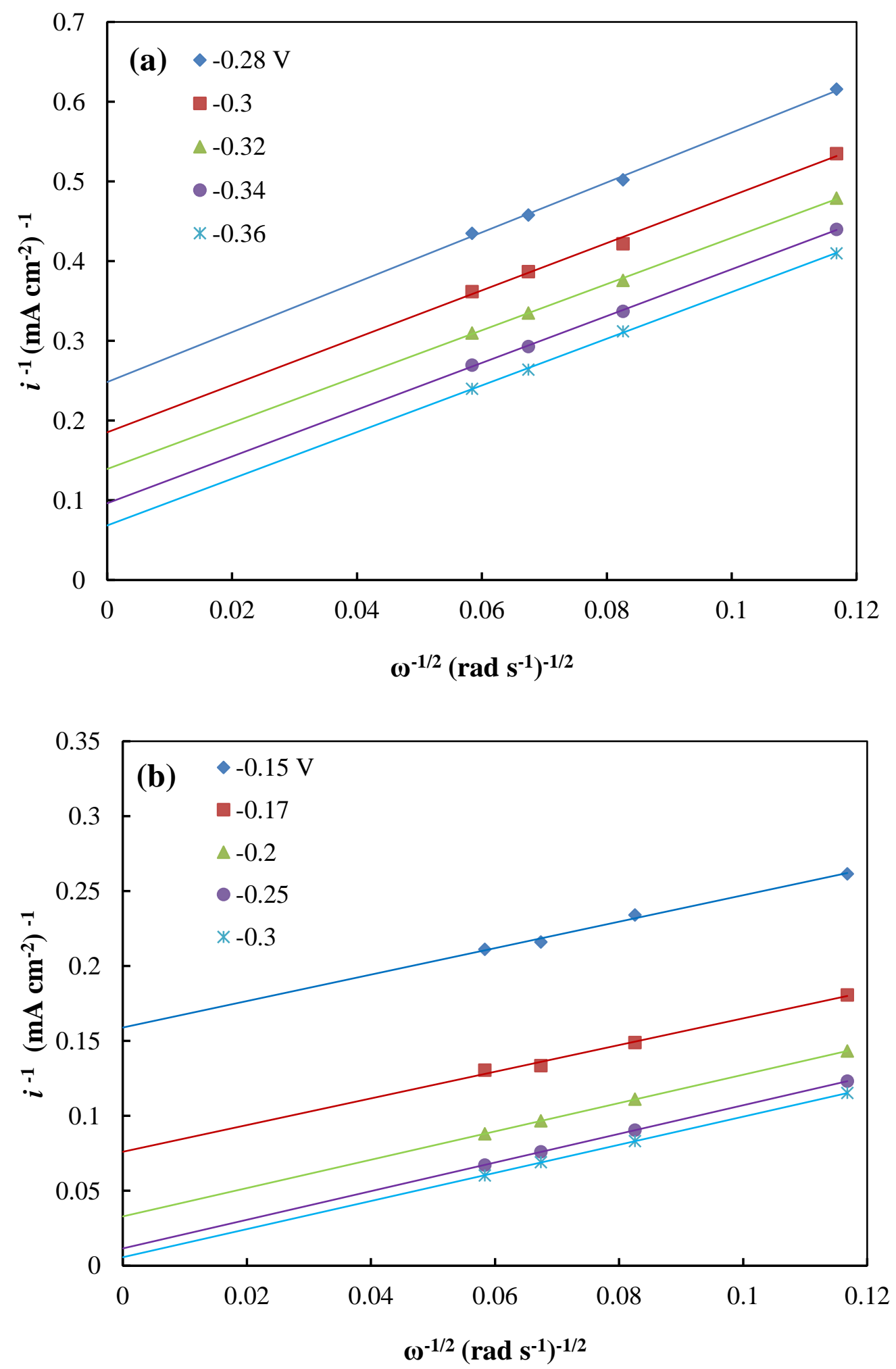

Fig. 7: Representative Koutechy-Levich plots for the reduction of $\mathrm{Cu}(\mathrm{I})$ species: (a) $1 \mathrm{wt} \%$ $\mathrm{H}_{2} \mathrm{O}$ (b) $15 \mathrm{wt} \% \mathrm{H}_{2} \mathrm{O}$. Experiments were performed using a Pt RDE at $\omega=700,1400,2100$ and $2800 \mathrm{rpm}$. The potential, $E$, at which the data was recorded is shown in the caption. 


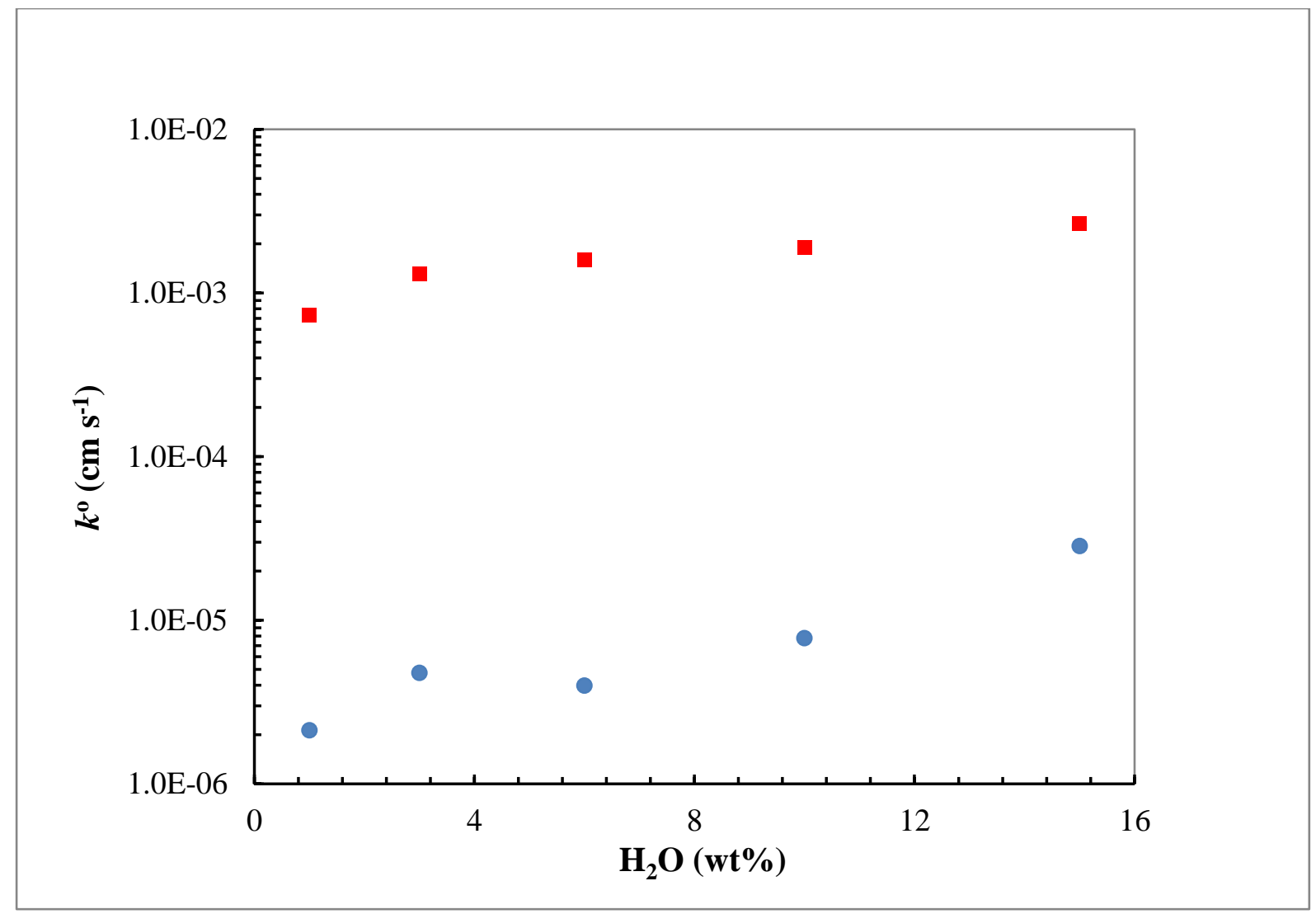

Fig. 8: The effect of water additions on the standard heterogeneous rate constant, $k^{0}$, for the reduction of $\mathrm{Cu}(\mathrm{II})$ complex $(\square)$ and $\mathrm{Cu}(\mathrm{I})$ complex (๑) in ethaline containing $0.20 \mathrm{M}$ $\mathrm{CuCl}_{2} \cdot 2 \mathrm{H}_{2} \mathrm{O}$. 


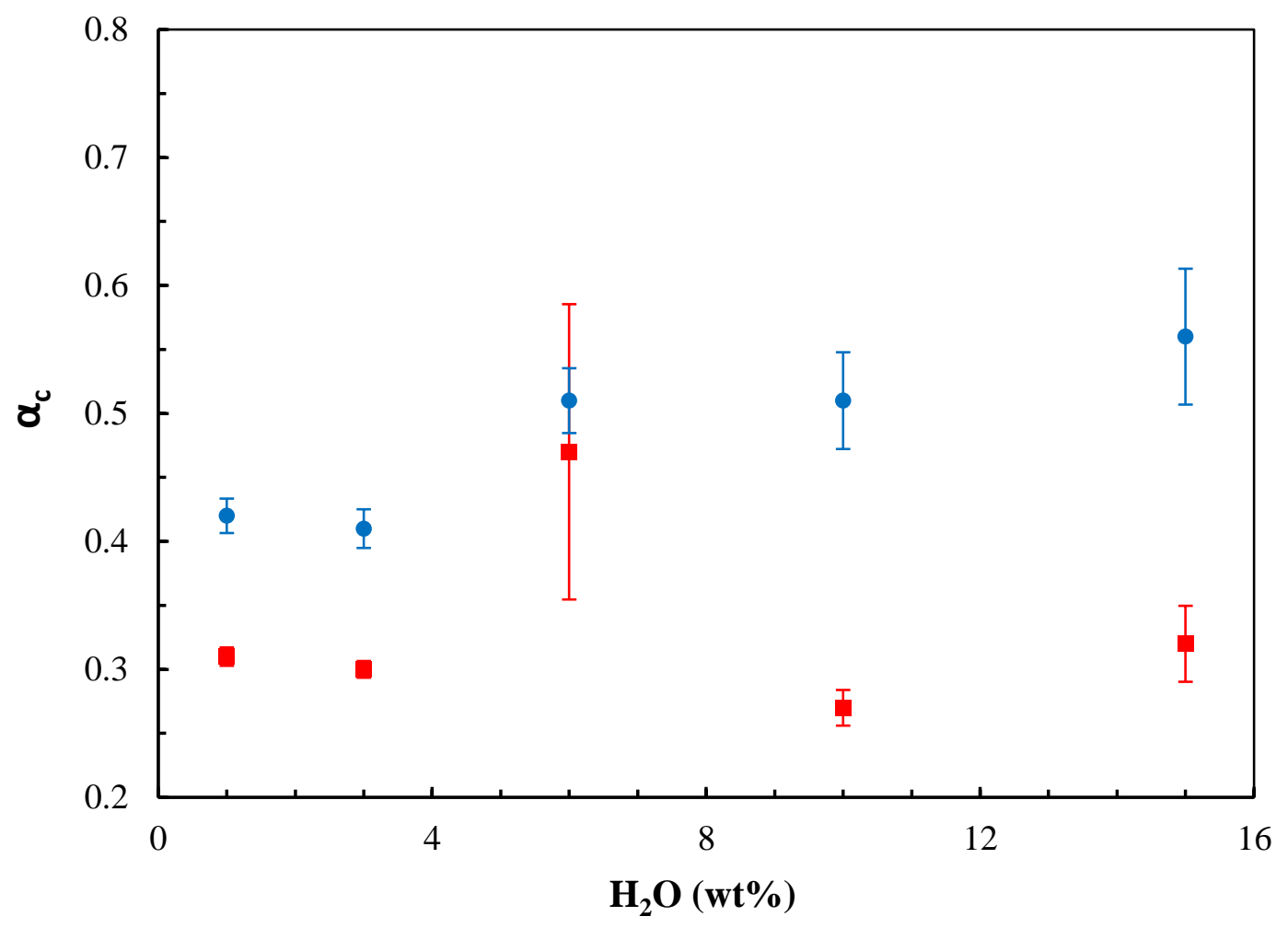

Fig. 9: The effect of water additions on the cathodic transfer coefficient, $\alpha_{c}$, for the reduction of $\mathrm{Cu}(\mathrm{II})$ complex ( $\square)$ and $\mathrm{Cu}(\mathrm{I})$ complex (๑) in ethaline containing $0.20 \mathrm{M} \mathrm{CuCl}_{2} .2 \mathrm{H}_{2} \mathrm{O}$. 

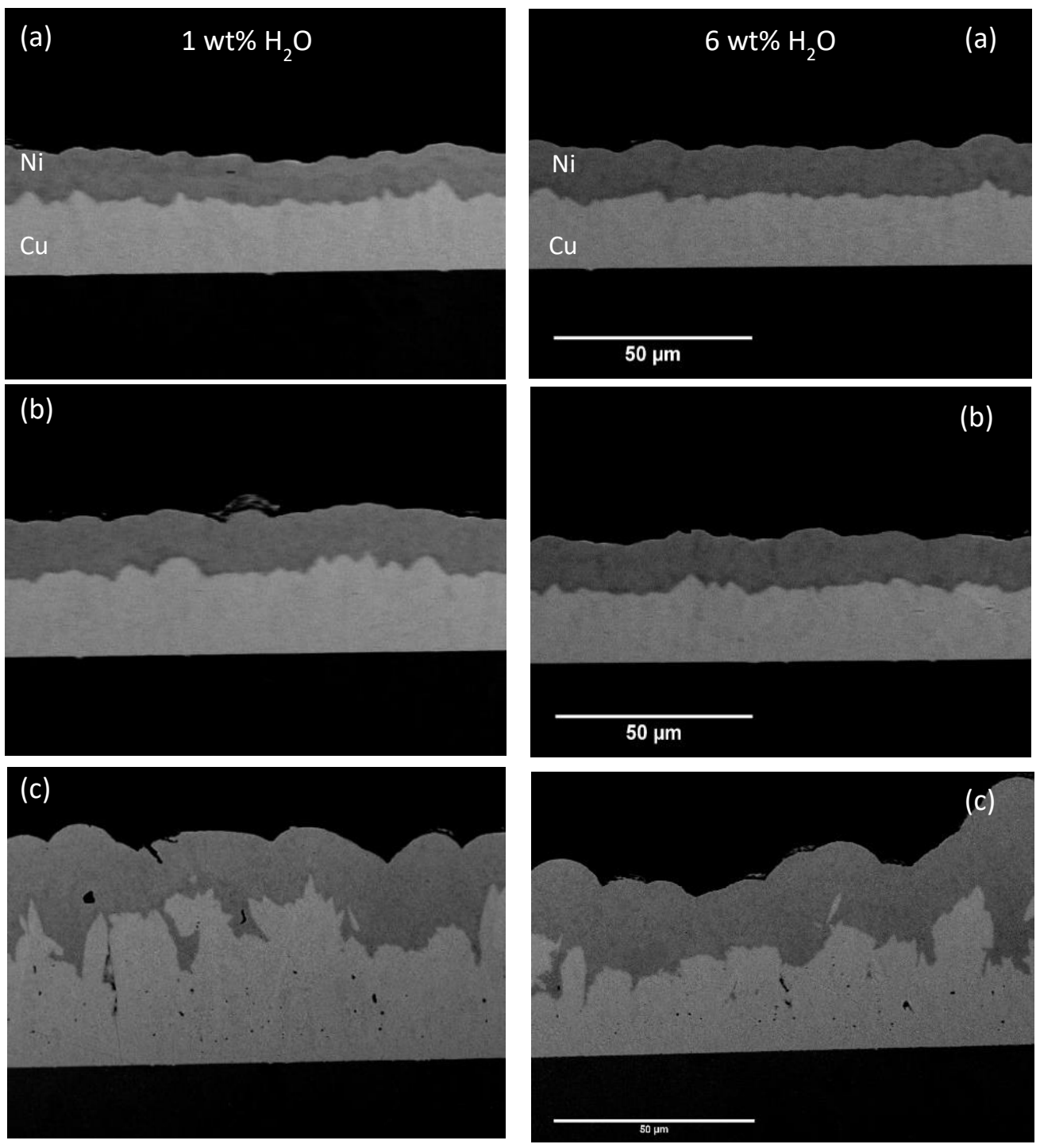

Fig. 10: SEM cross-sectional image of copper deposited from $0.20 \mathrm{M} \mathrm{CuCl}_{2} .2 \mathrm{H}_{2} \mathrm{O}$ in ethaline

(1 and $6 \mathrm{wt} \% \mathrm{H}_{2} \mathrm{O}$ ) as a function of the radial position on the RDE. (a) near centre, $r / r_{0}=0.06$

(b) mid-point, $r / r_{0}=0.50$ and (c) near edge, $r / r_{0}=0.87$. 


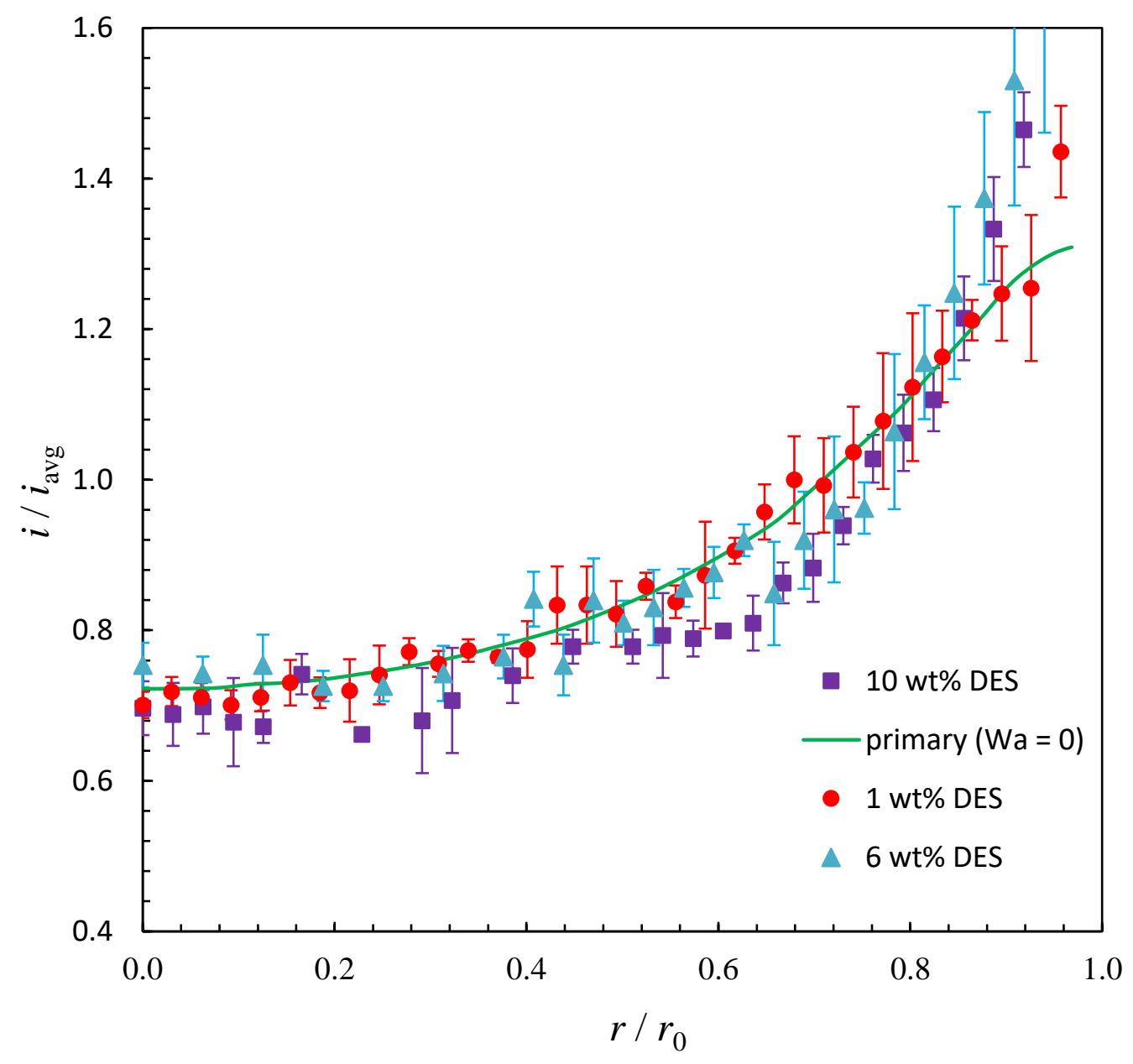

Fig. 11: Measured thickness distribution for copper deposited from $0.20 \mathrm{M} \mathrm{CuCl}_{2} \cdot 2 \mathrm{H}_{2} \mathrm{O}$ in ethaline $\left(1,6\right.$ and $\left.10 \mathrm{wt} \% \mathrm{H}_{2} \mathrm{O}\right)$. The green line represents the theoretical primary current distribution for the recessed RDE. 


\begin{tabular}{|c|c|c|c|c|c|c|c|}
\hline \multirow{2}{*}{$\begin{array}{c}\text { Water } \\
\text { Content } \\
(\text { wt\%) }\end{array}$} & \multirow{2}{*}{$\begin{array}{c}E_{\mathrm{w}} \text { vs Ag } \\
\text { RE } \\
\text { V }\end{array}$} & \multicolumn{2}{|c|}{$\begin{array}{c}i_{\lim } \\
\mathbf{m A ~} \mathrm{cm}^{-2}\end{array}$} & \multicolumn{2}{|c|}{$\begin{array}{c}D \\
/ 10^{-7} \mathrm{~cm}^{2} \mathrm{~s}^{-1}\end{array}$} & \multirow{2}{*}{$\begin{array}{c}\boldsymbol{E}^{\mathbf{0}^{\prime}} \text { vs } \mathbf{A g} \mathbf{R E} \\
\mathbf{V} \\
\mathrm{Cu}(\mathrm{II}) / \mathrm{Cu}(\mathrm{I})\end{array}$} & \multirow{2}{*}{$\begin{array}{c}\mathbf{E}^{0^{\prime}} \text { vs } \mathrm{Ag} \mathrm{RE} \\
\mathbf{V} \\
\mathrm{Cu}(\mathrm{I}) / \mathrm{Cu}(0)\end{array}$} \\
\hline & & $\mathrm{Cu}(\mathrm{II})$ & $\mathrm{Cu}(\mathrm{I})$ & $\mathrm{Cu}(\mathrm{II})$ & $\mathrm{Cu}(\mathrm{I})$ & & \\
\hline 1 & 2.11 & 3.0 & 2.4 & 1.29 & 1.00 & 0.531 & 0.002 \\
\hline 3 & 2.10 & 4.3 & 2.9 & 2.16 & 1.20 & 0.537 & -0.002 \\
\hline 6 & 2.07 & 4.4 & 4.1 & 2.11 & 1.90 & 0.543 & -0.008 \\
\hline 10 & 2.06 & 6.4 & 6.1 & 3.33 & 3.10 & 0.547 & -0.017 \\
\hline 15 & 2.02 & 9.0 & 9.1 & 5.07 & 5.09 & 0.571 & -0.027 \\
\hline
\end{tabular}

Table 1: Electrochemical window, $E_{\mathrm{w}}$, as a function of water content in pure ethaline. Also shown are the limiting currents and diffusion coefficients for the $\mathrm{Cu}$ (II) and $\mathrm{Cu}(\mathrm{I})$ species in ethaline containing $0.20 \mathrm{M} \mathrm{CuCl}_{2} \cdot 2 \mathrm{H}_{2} \mathrm{O}$ and the estimated formal potentials, $E^{0^{\prime}}$, for the redox couples. Measurements were performed at a Pt RDE with $\omega=700 \mathrm{rpm}$. 


\begin{tabular}{|c|c|c|c|c|}
\hline Electrolyte & $\begin{array}{c}\text { Temp } \\
{ }^{0} \mathrm{C}\end{array}$ & $\begin{array}{c}D \mathrm{Cu}(\mathrm{II}) \\
/ 10^{-7} \mathrm{~cm}^{2} \mathrm{~s}^{-1} \\
\end{array}$ & $\begin{array}{c}D \mathrm{Cu}(\mathrm{I}) \\
/ 10^{-7} \mathrm{~cm}^{2} \mathrm{~s}^{-1} \\
\end{array}$ & Ref. \\
\hline $1.5 \mathrm{M} \mathrm{NaCl}$ in $\mathrm{H}_{2} \mathrm{O}$ & 20 & 43 & 45 & [40] \\
\hline Ethaline DES & 20 & 2.42 & - & {$[22]$} \\
\hline Ethaline DES & 25 & 2.28 & 1.86 & {$[11]$} \\
\hline Ethaline DES & 25 & 1.50 & 2.70 & [39] \\
\hline Ethaline DES & 25 & 1.22 & - & {$[38]$} \\
\hline Ethaline DES & 25 & 1.3 & 1.0 & This work \\
\hline
\end{tabular}

Table 2: Selected diffusion coefficients for the $\mathrm{Cu}(\mathrm{II})$ and $\mathrm{Cu}(\mathrm{I})$ chloro-complexes in various electrolytes. For all DES systems, the water content is $<1 \mathrm{wt} \%$. 


\begin{tabular}{|c|c|c|c|c|c|c|}
\hline \multirow[b]{2}{*}{ Electrolyte } & \multirow[t]{2}{*}{$\begin{array}{l}\text { Electrode } \\
\text { Material }\end{array}$} & \multicolumn{2}{|c|}{$\mathrm{Cu}(\mathrm{II}) / \mathrm{Cu}(\mathrm{I})$} & \multicolumn{2}{|c|}{$\mathbf{C u}(\mathbf{I}) / \mathbf{C u}(0)$} & \multirow[t]{2}{*}{ Ref. } \\
\hline & & $\alpha_{c}$ & $\begin{array}{c}k^{0} \\
/ 10^{-3} \mathrm{~cm} \mathrm{~s}^{-1}\end{array}$ & $\alpha_{c}$ & $\begin{array}{c}k^{0} \\
/ 10^{-3} \mathrm{~cm} \mathrm{~s}^{-1}\end{array}$ & \\
\hline $8 \mathrm{~mol} \mathrm{~kg}^{-1} \mathrm{HCl}$ in $\mathrm{H}_{2} \mathrm{O}$ & $\mathrm{Pt}$ & $0.55 \pm 0.17$ & 4.10 & - & - & [44] \\
\hline $0.5 \mathrm{M} \mathrm{KCl}$ in $\mathrm{H}_{2} \mathrm{O}$ & GC & $0.49 \pm 0.03$ & 4.60 & - & - & [43] \\
\hline Reline DES & $\mathrm{Pt}$ & 0.32 & 1.15 & - & - & {$[41]$} \\
\hline Ethaline DES & $\mathrm{Pt}$ & - & 0.27 & - & 1.29 & [11] \\
\hline Ethaline DES & $\mathrm{Pt}$ & 0.52 & 0.18 & - & - & [46] \\
\hline Ethaline DES & $\mathrm{Pt}$ & $0.39 \pm 0.03$ & 1.0 & - & - & {$[42]$} \\
\hline Ethaline DES & $\mathrm{Pt}$ & $0.25 \pm 0.05$ & 0.95 & - & - & [39] \\
\hline Ethaline DES & $\mathrm{Pt}$ & $0.31 \pm 0.02$ & 0.73 & $0.42 \pm 0.02$ & 0.0021 & This work \\
\hline
\end{tabular}

Table 3: Selected kinetic parameters for the $\mathrm{Cu}(\mathrm{II}) / \mathrm{Cu}(\mathrm{I})$ and $\mathrm{Cu}(\mathrm{I}) / \mathrm{Cu}(0)$ redox couples in different electrolytes at $25{ }^{\circ} \mathrm{C}$. For all DES systems, the water content is $<1 \mathrm{wt} \%$. 


\begin{tabular}{|c|c|c|c|c|c|}
\hline Electrolyte & wt \% $\mathrm{H}_{2} \mathrm{O}$ & $\begin{array}{c}\kappa \\
S \text { m }^{-1} \\
\end{array}$ & $\begin{array}{c}i_{\text {avg }} \\
\mathrm{mA} \mathrm{cm}^{-2} \\
\end{array}$ & $\alpha$ & $W_{\mathbf{a}}$ \\
\hline \multirow{5}{*}{$\begin{array}{l}0.20 \mathrm{M} \mathrm{CuCl}_{2} \text { in } \\
\text { Ethaline DES }\end{array}$} & 1 & 0.795 & 4.7 & 0.42 & 0.17 \\
\hline & 3 & 0.953 & 5.6 & 0.41 & 0.18 \\
\hline & 6 & 1.02 & 6.6 & 0.51 & 0.13 \\
\hline & 10 & 1.16 & 9.8 & 0.51 & 0.10 \\
\hline & 15 & 1.53 & 14.1 & 0.56 & 0.08 \\
\hline
\end{tabular}

Table 4: Calculated Wagner number, $W_{\mathrm{a}}$, at a $\operatorname{RDE}(\omega=700 \mathrm{rpm})$ based on the measured values of $\alpha$ and $\kappa$, with $i_{\text {avg }}=0.8 \times i_{\text {lim }}$ and a characteristic length equal to the RDE radius $\left(r_{0}\right.$ $=0.6 \mathrm{~cm})$. 